\title{
Synthesis of carboxamide containing tranylcypromine analogues as LSD1 (KDM1A) inhibitors targeting acute myeloid leukemia
}

\author{
Maria Teresa Borrello, ${ }^{[a]}$ Hanae Benelkebir, ${ }^{[a]}$ Adam Lee,${ }^{[a]}$ Chak Hin Tam, ${ }^{[a]}$ Manar Shafat,${ }^{[b]}$ Stuart A. \\ Rushworth, ${ }^{[b]}$ Kristian M. Bowles, ${ }^{[b]}$ Leon Douglas, ${ }^{[c]}$ Patrick J. Duriez, ${ }^{[c]}$ Sarah Bailey, ${ }^{[c]}$ Simon J. \\ Crabb, ${ }^{[\mathrm{c}]}$ Graham Packham, ${ }^{[\mathrm{c}]}$ and A. Ganesan ${ }^{*[a]}$
}

In memory of the late Professor Maurizio Botta 1950-2019 for his generous friendship and his many outstanding scientific contributions to medicinal chemistry.

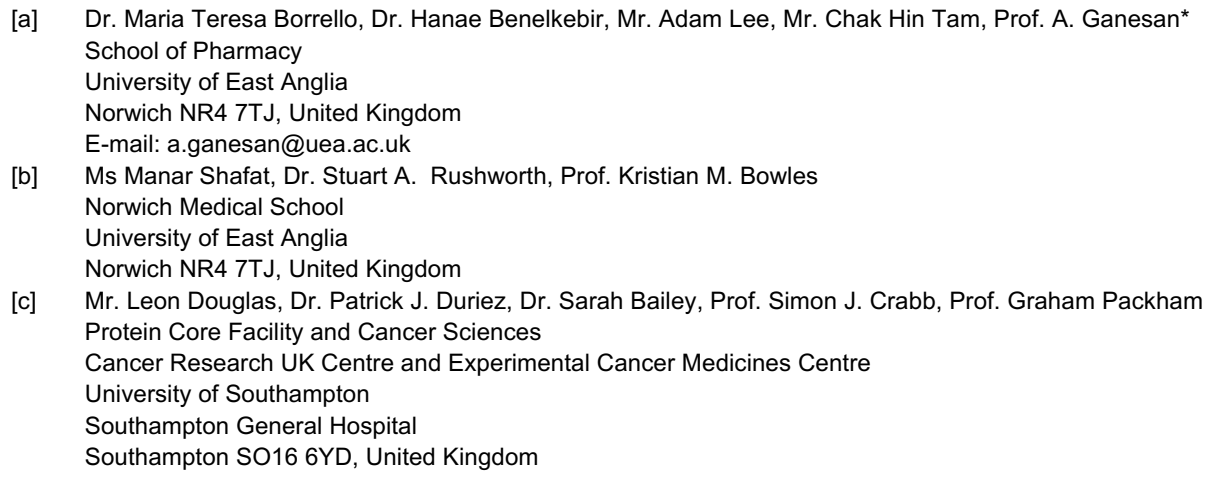

Supporting information for this article is given via a link at the end of the document.

\begin{abstract}
Lysine-specific demethylase 1 (LSD1/KDM1A) oxidatively removes methyl groups from histone proteins and its aberrant activity has been correlated with cancers including acute myeloid leukemia (AML). We report a novel series of tranylcypromine analogues with a carboxamide at the 4-position of the aryl ring. These compounds, such as $\mathbf{5 a}$ and $\mathbf{5 b}$, had potent submicromolar IC 50 values for the inhibition of LSD1 as well as cell proliferation in a panel of AML cell lines. The dose-dependent increase in cellular expression levels of $\mathrm{H} 3 \mathrm{~K} 4 \mathrm{me} 2, \mathrm{CD} 86, \mathrm{CD} 11 \mathrm{~b}$ and $\mathrm{CD} 14$ supported a mechanism involving LSD1 inhibition. The $t$-butyl and ethyl carbamate derivatives of these tranylcypromines, although inactive in LSD1 inhibition, were of similar potency in cell-based assays with a more rapid onset of action. This suggests carbamates can act as metabolically labile tranylcypromine prodrugs with superior pharmacokinetics.
\end{abstract}

\section{Introduction}

Lysine methyltransferases (KMTs) catalyse the addition of one, two or three methyl groups to the lysine side chains in proteins. ${ }^{[1]}$ The process is dynamically reversible due to lysine demethylases (KDMs) which carry out $\mathrm{C}-\mathrm{H}$ oxidation of the methyl group to a carbinolamine that undergoes hydrolysis to formaldehyde and the demethylated lysine. KDM1 comprising the two lysine-specific demethylase (LSD) isoforms LSD1 and LSD2 employs FAD (flavin adenine dinucleotide) as the oxidant. In addition, the approximately twenty human isoforms of KDM27 are iron(II)-dependent dioxygenases also known as Jumonji C (JmjC) demethylases. Targeting the FAD or iron cofactors respectively within these two families of KDM enzymes has emerged as a successful strategy for the design of selective inhibitors. ${ }^{[2,3]}$

LSD1 (KDM1A) contains SWIRM (Swi3, Rsc8 and Moira) and Tower domains that modulate its incorporation into transcriptionally activating or repressive multiprotein assemblies. As part of the CoREST (REST corepressor 1) and NuRD (nucleosome remodeling and histone deacetylase) complexes, LSD1 demethylates the nucleosome at histone H3K4 residues leading to gene silencing. Meanwhile, association with androgen or estrogen receptors promotes $\mathrm{H} 3 \mathrm{~K} 9$ demethylation and gene activation. These events are linked to cell proliferation in leukemia and hormone-dependent cancers as well as the maintenance of cancer stem cells resistant to therapy. ${ }^{[4]}$ Further validation of LSD1 for epigenetic drug discovery comes from its high expression levels in other cancer types including sarcoma, neuroblastoma, bladder, gastric and lung..$^{[5,6]}$

One approach to targeting LSD1 involves the repurposing of monoamine oxidase (MAO) inhibitors that disrupt the FAD cofactor common to both enzymes. ${ }^{[7,8]}$ The approved antidepressant $( \pm)$-tranylcypromine (1, Figure 1$)$ for example, is a substrate mimic that is oxidized to radical cation $\mathbf{2}$, followed by strain induced cyclopropyl ring opening to the reactive intermediate 3 which covalently modifies FAD. Since the cofactor is tightly bound to LSD1, with one study reporting a $\mathrm{K}_{d}$ of $180 \mathrm{nM},{ }^{[9]}$ the formation of tranylcypromine-FAD adducts effectively results in irreversible enzyme inactivation. While tranylcypromine is consequently being reinvestigated in clinical trials as an anticancer agent, it has a modest micromolar potency against LSD1 and inhibits MAO equally. Both the LSD1 potency and selectivity are improved in second-generation analogues featuring substitution of the aryl ring or the nitrogen (or both). ${ }^{[10]}$ One series 4 with a para-anilide substituent was 
independently reported by Mai and Takeda. ${ }^{[11-16]}$ We were interested in the 'reverse amide' isosteres $\mathbf{5}$ and while our studies were in progress, a Takeda patent disclosed similar structures. ${ }^{[17]}$ Nevertheless, only compound $\mathbf{5 a}$ below was described and the rest of our analogues are unique to this work. In parallel, we explored a sulfonamide series $\mathbf{6}$ which we have recently published. ${ }^{[18]}$
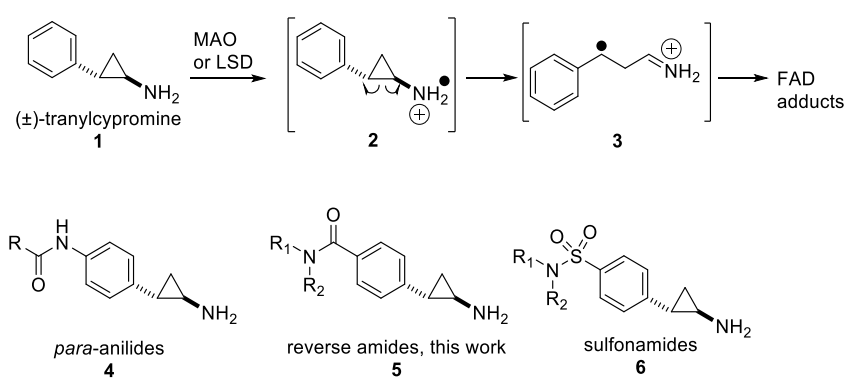

Figure 1. Mechanism of action of ( \pm )-tranylcypromine 1 and examples of parasubstituted second-generation analogues $( \pm)$-4-6.

\section{Results and Discussion}

\section{Chemistry - analogue synthesis}

Typically, the tranylcypromine scaffold is obtained from a carboxylic acid precursor which in turn arises from the $[2+1]$ cyclization of arylalkenes with carbenoid or carbanion synthons. In our synthetic route, 4-formylbenzoic acid (7, Scheme 1$)$ was protected as the methyl ester $\mathbf{8}$, followed by a HornerWadsworth-Emmons olefination with $t$-butyl diethylphosphonoacetate to provide the differentially protected cinnamate 9. A Johnson-Corey-Chaykovsky cyclopropanation installed the three membered ring in 10 with the trans configuration as confirmed by the ${ }^{1} \mathrm{H}-{ }^{1} \mathrm{H}$ coupling constants of the cyclopropyl moiety $\left(J_{\mathrm{ab}}=4.2-4.5 \mathrm{~Hz}\right)$. Selective acidic removal of the $t$-butyl ester afforded the monoacid 11 which was reacted with diphenylphosphoryl azide followed by Curtius rearrangement and trapping of the resulting isocyanate with $t$ butanol to give Boc protected tranylcypromine 12. The methyl ester was then hydrolyzed to give the common intermediate 13 which was coupled with a set of primary and secondary amines. Boc deprotection of the resulting amides $14 a-p$ completed the synthesis of the desired tranylcypromine analogues $( \pm) \mathbf{5 a}-\mathbf{p}$.

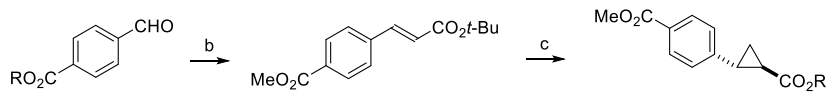

$7, \mathrm{R}=\mathrm{H}$

$( \pm)-10, R=t-B$
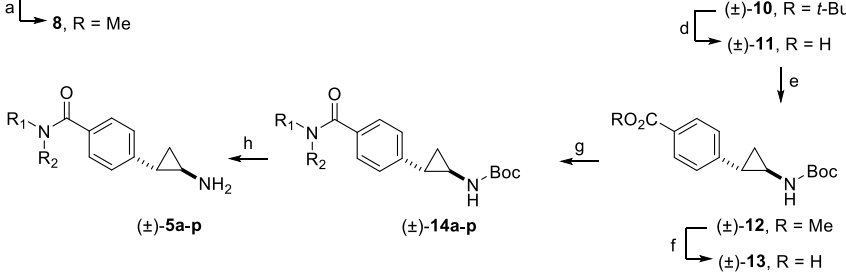

Scheme 1. Synthesis of tranylcypromine analogues $\mathbf{5 a - p}$. a) $\mathrm{AcCl}, \mathrm{MeOH}, 0$ ${ }^{\circ} \mathrm{C}$ to rt, overnight, $91 \%$; b) $t$-butyl diethylphosphonoacetate, $\mathrm{KOt}$-Bu, THF, $-5^{\circ}$ $\mathrm{C}$ to rt, overnight, $98 \%$; c) $\mathrm{Me}_{3} \mathrm{~S}(\mathrm{O})^{+} \mathrm{I}$, $\mathrm{KOt}-\mathrm{Bu}$, DMSO, rt, overnight, $53 \%$; d)
TFA, $\mathrm{Et}_{3} \mathrm{SiH}, \mathrm{CH}_{2} \mathrm{Cl}_{2}$, rt, overnight, $72 \%$; e) diphenylphosphoryl azide, $\mathrm{Et}_{3} \mathrm{~N}$, $t$ $\mathrm{BuOH}$, reflux, $72 \mathrm{~h}, 42 \%$; f) LiOH, aq THF, $50{ }^{\circ} \mathrm{C}, 2 \mathrm{~h}, 82 \%$; g) $\mathrm{R}_{1} \mathrm{R}_{2} \mathrm{NH}, \mathrm{EDCl}$, HOBt, i-Pr ${ }_{2} \mathrm{NEt}$, rt, overnight, $36-67 \%$; h) $\mathrm{HCl}$, THF, $13-71 \%$.

Biology- LSD1 inhibition and antiproliferative activity against AML cell lines

Tranylcypromine analogues $\mathbf{5}$ were investigated for their LSD1 inhibitory activity with a fluorescence-based LSD1 enzymatic assay according to our previously published procedure. Briefly, the assay uses a synthetic dimethylated histone $\mathrm{H} 3 \mathrm{~K} 4 \mathrm{me} 2$ peptide as substrate and AmplexRed ${ }^{\circledR}$ detection of the $\mathrm{H}_{2} \mathrm{O}_{2}$ byproduct. ${ }^{[19]}$ While tranylcypromine itself had a $\mathrm{IC}_{50}$ of $21.0 \mu \mathrm{M}$ in this assay, the analogues were significantly more potent LSD1 inhibitors with the exception of $\mathbf{5 h}$ and $\mathbf{5 i}$ (Table $\mathbf{1}$ ). Compounds 5a-c containing an aryl or heteroaryl substituent linked by a one or two carbon spacer to the carboxamide were submicromolar inhibitors of the enzyme. Switching to the non-aromatic cyclohexyl isosteres $\mathbf{5 d} \mathbf{d}-\mathbf{e}$ led to a loss of activity suggesting that $\pi-\pi$ interactions might be important within the enzyme active site. In the benzyl compound $\mathbf{5 a}$, para substitution as in $\mathbf{5 f - 5 i}$ led to reduced activity, most dramatically with the methoxy and biphenyl analogues. We additionally synthesized the tertiary amides $\mathbf{5 j}$ with a dibenzyl group and $\mathbf{5 k} \mathbf{- 5 p}$ containing a 4 aminopiperazine moiety. These tertiary amides, however, did not exhibit a gain in potency compared to the simpler secondary amides.

Table 1. LSD1 enzyme inhibition by tranylcypromine analogues ( \pm )-5a-p. $I C_{50}$ values are reported in $\mu M \pm \operatorname{SEM}(n=3)$.

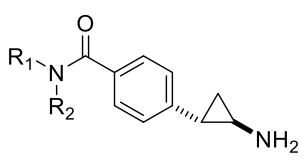

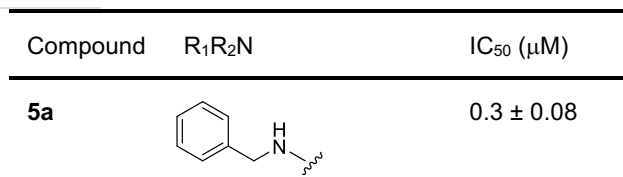

$5 b$<smiles>CCNCCc1ccccc1</smiles>

$0.4 \pm 0.04$

$5 c$

$0.6 \pm 0.08$<smiles>CCNCCc1cccs1</smiles>

5d<smiles>CC(C)NCC1CCCCC1</smiles>

$5 e$

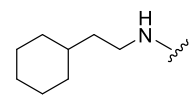

$2.4 \pm 0.99$

$5.8 \pm 0.47$

$5 f$

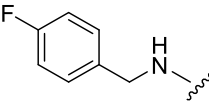

$1.3 \pm 0.26$

$5 g$

$0.9 \pm 0.18$ 
$5 h$<smiles>CCCCCCCCCNCc1ccc(OC)cc1</smiles>

$32.0 \pm 0.25$

$5 i$<smiles>[Y16]=[As]=[W]</smiles>

$5 j$<smiles>CN(Cc1ccccc1)Cc1ccccc1</smiles>

$5 k$<smiles>CN1CCN(c2ccccn2)CC1</smiles><smiles>CN1CCN(c2ncccn2)CC1</smiles>

$5 \mathrm{~m}$<smiles>Cc1ccc(S(=O)(=O)N2CCN(C)CC2)cc1</smiles>

$5 n$<smiles>CN1CCN(S(C)(=O)=O)CC1</smiles>

50<smiles>CN1CCN(c2ccccc2F)CC1</smiles>

$0.5 \pm 0.04$

$1.8 \pm 0.3$
$1.5 \pm 0.2$

$1.8 \pm 0.05$

$0.7 \pm 0.09$

$0.5 \pm 0.01$

$0.9 \pm 0.01$

Based on the enzyme assay results, selected analogues were tested for their growth inhibitory potential against acute myeloid leukemia (AML) cell lines. We selected a panel that included both the wild type MLL (mixed lineage leukemia) gene (U937, $\mathrm{HL}-60$ and $\mathrm{OCl}-\mathrm{AML} 3$ ) as well as MLL fusions arising from gene translocation (Kasumi-1: MLL-ETO; THP-1: MLL-AF9; MV4-11: MLL-AF4), since the latter are particularly sensitive to differentiation and reduced cell proliferation following LSD1 inhibition. ${ }^{[20]}$ After 72 hours incubation, tranylcypromine was found to have low antiproliferative activity, with $I C_{50}$ values $>50$ $\mu \mathrm{M}$ in five of the six cell lines tested (Table 2). On the other hand, the analogues with a benzylamide $(\mathbf{5 a}, \mathbf{5 f})$ or a phenethylamide (5b, 5c) arrested proliferation of at least one cell line at submicromolar concentrations. The cellular activity generally tracked with the inhibition observed in the enzyme assay.

Table 2. Antiproliferative activity of tranylcypromine (1) and tranylcypromine analogues (5) in AML cancer cell lines. Blank cells indicate the assay was not performed with that cell line.

\begin{tabular}{|c|c|c|c|c|c|c|}
\hline & Kasumi-1 & U937 & $\mathrm{HL}-60$ & OCI-AML3 & THP-1 & MV4-11 \\
\hline \multicolumn{7}{|c|}{$\mathrm{IC}_{50}$ values in $\mu \mathrm{M} \pm$ SEM $(\mathrm{n}=5)$} \\
\hline 1 & $32 \pm 1.8$ & $>100$ & $84 \pm 15.0$ & $89 \pm 13.0$ & $81 \pm 3.9$ & $63 \pm 8.4$ \\
\hline $5 a$ & $0.3 \pm 0.01$ & $1.6 \pm 0.4$ & $1.7 \pm 0.4$ & $1.8 \pm 0.8$ & $0.1 \pm 0.1$ & $18.1 \pm 7.2$ \\
\hline $5 b$ & $0.7 \pm 0.02$ & $1.2 \pm 0.2$ & $0.9 \pm 0.07$ & $0.6 \pm 0.5$ & $2.7 \pm 0.2$ & $19.0 \pm 3.6$ \\
\hline $5 c$ & $0.4 \pm 0.08$ & $0.6 \pm 0.1$ & $6.3 \pm 0.1$ & & $1.0 \pm 0.1$ & $1.7 \pm 0.8$ \\
\hline $5 d$ & $2.4 \pm 0.5$ & $6.0 \pm 0.8$ & $3.4 \pm 1.2$ & & & $12.0 \pm 0.5$ \\
\hline $5 e$ & $31.0 \pm 2.7$ & & & & & $1.0 \pm 0.2$ \\
\hline $5 f$ & $0.6 \pm 0.08$ & & & & $0.4 \pm 0.1$ & $2.0 \pm 0.7$ \\
\hline $5 g$ & $2.7 \pm 0.1$ & $34.7 \pm 3.4$ & $>100$ & $>100$ & $>100$ & $20 \pm 2.3$ \\
\hline 51 & $2.3 \pm 1.4$ & $>100$ & $6.1 \pm 0.3$ & $>100$ & $>100$ & $>100$ \\
\hline $5 n$ & $>100$ & & & & & $2.0 \pm 0.7$ \\
\hline 50 & & & $1.8 \pm 0.2$ & $2.0 \pm 0.1$ & & \\
\hline $5 p$ & $3.3 \pm 0.6$ & & $0.3 \pm 0.1$ & & & \\
\hline
\end{tabular}

\section{Biology- mechanism of inhibition and effects on biomarkers}

The nature of cellular enzyme inhibition was examined with the analogues 5a-c through a washout experiment. Cells were exposed to the compounds for a short period of 6 hours, after which the culture medium was washed out and replaced by fresh medium without the inhibitors (Figure 2).

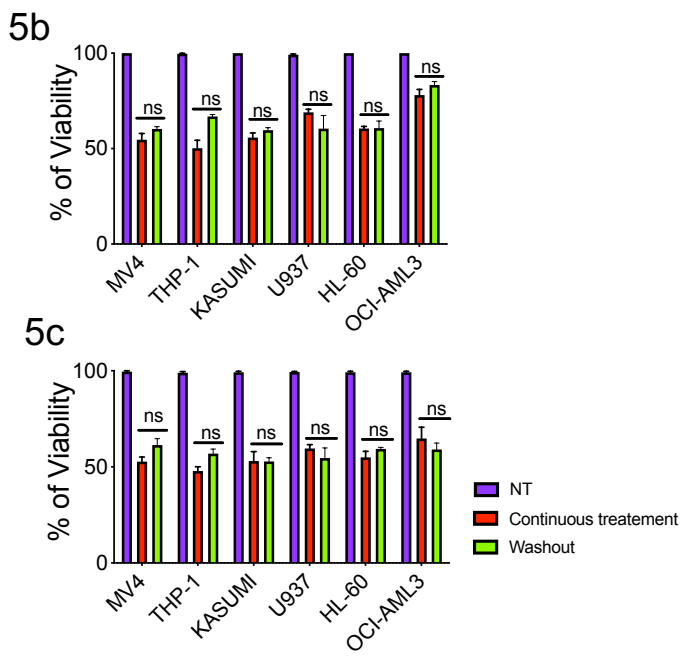

Figure 2. Washout experiment. AML cell lines were treated with $200 \mathrm{nM}$ of compound 5b,c respectively for $6 \mathrm{~h}$ followed by washout, or for $72 \mathrm{~h}$ continuously. The percentage viability was measured with Cell-Titer-Glo ${ }^{\circledR}$ and relative luminescence units (RLU) normalised to DMSO control (NT, nontreated, vehicle). Statistical analysis using two-way ANOVA and corrected for multiple comparisons using Bonferoni's test revealed non-significant (ns) variations in cells viability was found between non-treated, treated continuous and wash-out. The results are expressed as percentage of viability compared to controls. Errors bars are mean \pm SEM ( $n=5$ and three technical replicates). 
To demonstrate LSD1 inhibition through cellular biomarkers, we selected $\mathbf{5 b}$ as this phenethylamide compound displayed a high level of activity in the enzyme assay as well as growth inhibition of both MLL-fusion cell lines (e.g. MLL-AF4 in MV4-11 and MLLAF9 in THP-1) and wild type MLL (e.g. HL-60). MV4-11 cells were incubated with $\mathbf{5 b}(200 \mathrm{nM})$ for time periods of $2,4,6,48$ and 72 hours. After 48 and 72 hours, a time-dependent increase of $\mathrm{H} 3 \mathrm{~K} 4 \mathrm{me} 2$ was observed (Figure 3), consistent with the inhibition

A
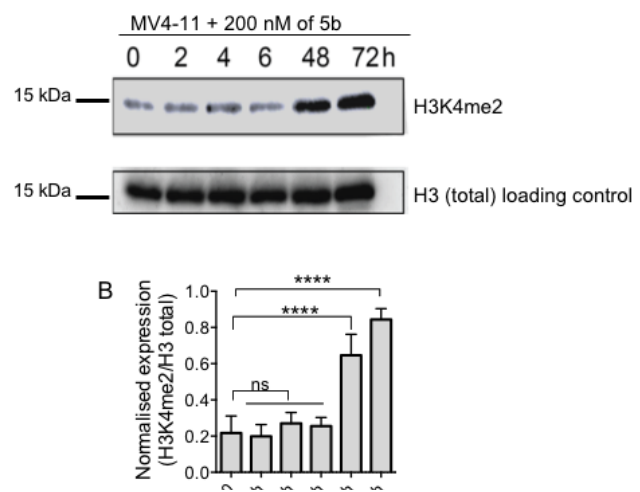

Figure 3: H3K4me2 expression upon compound 5b treatment on MV4-11 cell line. A. Immunoblot of $\mathrm{H} 3 \mathrm{~K} 4 \mathrm{me} 2$ and $\mathrm{H} 3$ (loading control) of cell lysates prepared from MV4-11 cell line treated with compound $\mathbf{5 b}$. B. Quantification of A using Image J software. Mean band intensity plotted \pm SEM $(n=3)$; One-way ANOVA was used for statistical analysis $\left({ }^{* * * *} p<0.0001, n=3\right)$. The figure is representative of three independent biological experiments.

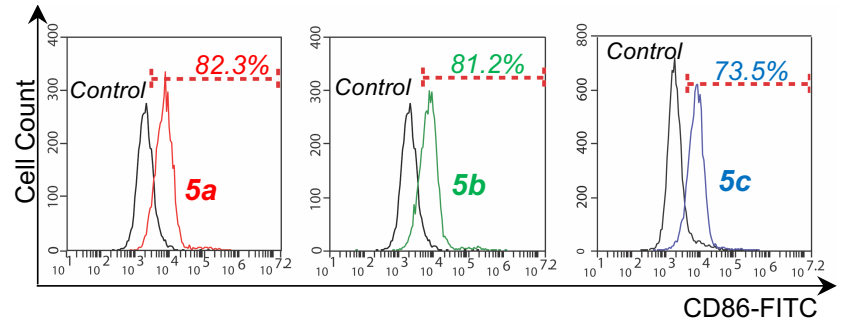

Figure 4. Evaluation of CD86 expression in MV4-11 cells upon treatment with $5 \mathrm{a}, 5 \mathrm{~b}$ and $5 \mathrm{c}(200 \mathrm{nM}, 48 \mathrm{~h}$ incubation). Cells were gated based on forward scatter (FSC) and side scatter (SSC) parameters. The $X$-axis indicates the mean fluorescence increase of CD86-FITC stained cells. Percentage of increase is reported compared to DMSO treated control cells. The figure is representative of three biological replicates with three technical replicates.

Further evidence for cellular LSD1 inhibition came from the increased levels of myeloid-differentiation associated cell surface proteins. CD86 (cluster of differentiation 86), a linker of the coinhibitory immune response of the CTL4 and CD86 receptor, is among the most highly upregulated genes following LSD1 inhibition and a convenient cellular biomarker. ${ }^{[21]}$ Treatment of AML cell lines with $\mathbf{5 a}, \mathbf{5 b}$ and $\mathbf{5 c}$ followed by FACS sorting analysis revealed a $70-90 \%$ increase in the expression of CD86 compared to control samples (Figure 4). In addition, we examined the levels of CD11b and CD14, two glycoproteins on the myeloid cell surface that are exclusively expressed in mature leucocytes and not in undifferentiated cells. As anticipated, $\mathbf{5 a}$ and $\mathbf{5 b}$ triggered cell differentiation as confirmed by a significant increase in CD11b and CD14 expression (Figure 5).
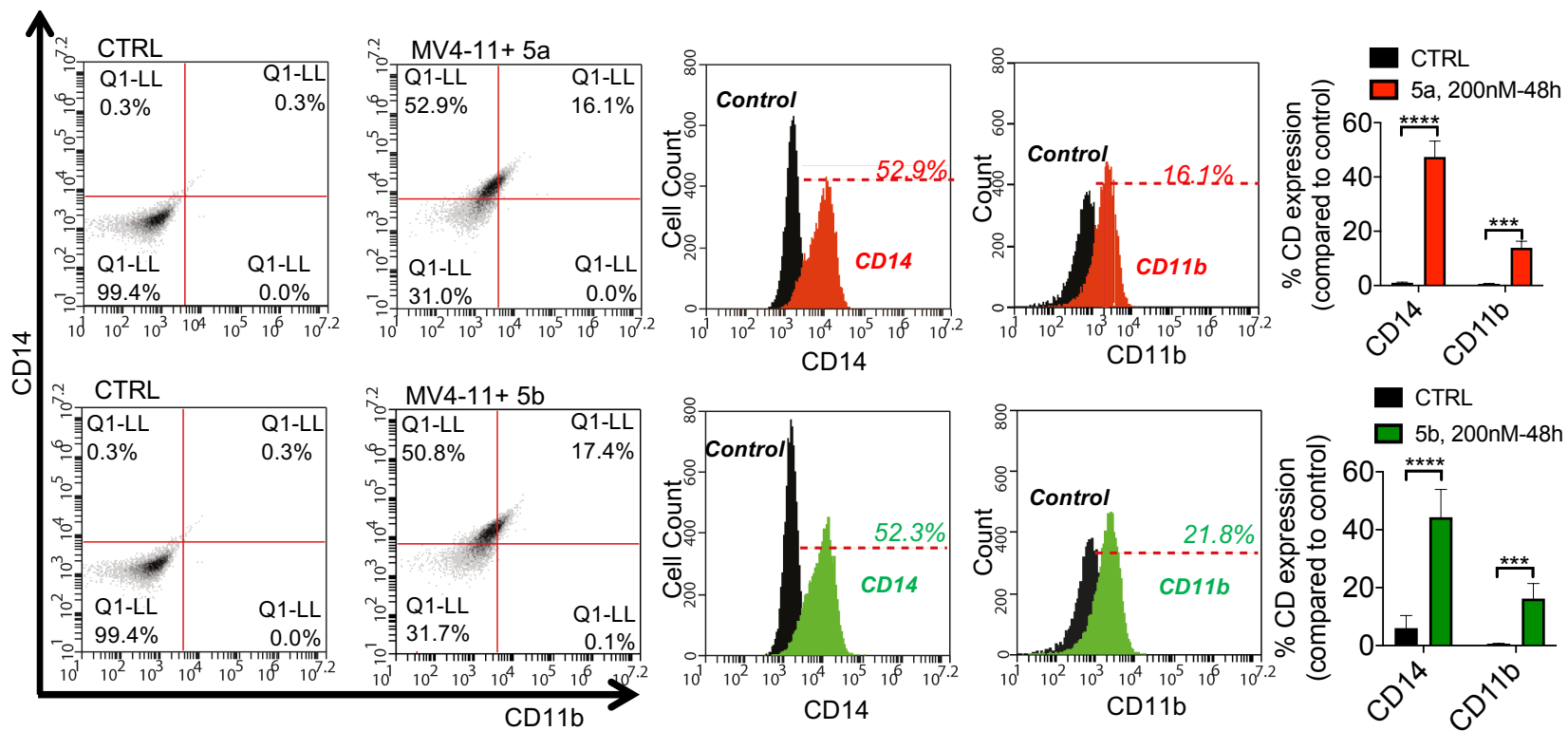

Figure 5. Effect of compounds $5 \mathrm{a}$ and $5 \mathrm{~b}(200 \mathrm{nM}, \mathbf{4 8 h})$ on the expression of CD14 and CD11b. FSC and SSC profiles were applied for the initial gating by selecting cell size and distribution and removal of cell debris. Plot $\mathbf{A}$ shows the isotype controls; $\mathbf{B}$ and $\mathbf{C}$ show the expression of CD11b and CD14 upon treatment with $\mathbf{5 a}$ and $\mathbf{5 b}$ respectively. Statistical significance was determined with two-way ANOVA and corrected for multiple comparisons with Bonferroni's test. Values are expressed as means $\%$ of CD14-CD11b increase \pm SD $(n=3)$; ${ }^{* * *} p<0.0001$. The reported figure is representative of three independent experiments. 


\section{Biology - tranylcypromine versus carbamate derivatives}

The mechanism of action of tranylcypromine (Figure 1) requires the lone pair of electrons in the amine to undergo oxidation by the FAD cofactor. As expected, the Boc protected precursors 14 of our analogues 5 were inactive in enzyme inhibition assays at the highest tested concentration of $250 \mu \mathrm{M}$ even at prolonged exposure times of 72 and 96 hours. However, to our surprise, the Boc carbamates displayed significant growth inhibition of the AML cell lines as illustrated for $14 b$ and $14 c$ (Figure 6 ), the protected versions of $\mathbf{5 b}$ and $\mathbf{5 c}$ respectively (Table 3 and Supplementary Figure S2-S8). Furthermore, while the tranylcypromines required incubation periods of 72 hours, significant reduction of cell survival was observed with the carbamates at shorter exposures of 24 and 48 hours.
Table 3. Antiproliferative activity of Boc protected tranylcypromines 14b,c and 15b,c in AML cancer cell lines. Blank cells indicate the assay was not performed with that cell line.

\begin{tabular}{lcccccc}
\hline & Kasumi-1 & U937 & HL-60 & OCI-AML3 & THP-1 & MV4-11 \\
\hline \multicolumn{5}{c}{$\mathrm{IC}_{50}$ values in $\mu \mathrm{M} \pm$ SEM $(\mathrm{n}=5)$} \\
\hline $\mathbf{5 b}$ & $0.7 \pm 0.02$ & $1.2 \pm 0.2$ & $0.9 \pm 0.07$ & $0.6 \pm 0.5$ & $2.7 \pm 0.2$ & $19.0 \pm 3.6$ \\
$\mathbf{1 4 b}$ & $0.5 \pm 0.03$ & $0.4 \pm 0.04$ & $0.4 \pm 0.02$ & $0.4 \pm 0.02$ & $0.2 \pm 0.04$ & $0.5 \pm 0.01$ \\
$\mathbf{1 5 b}$ & & $0.3 \pm 0.03$ & $0.5 \pm 0.08$ & $1.4 \pm 0.5$ & & $1.3 \pm 0.3$ \\
$\mathbf{5 c}$ & $0.4 \pm 0.08$ & $0.6 \pm 0.1$ & $6.3 \pm 0.1$ & & $1.0 \pm 0.1$ & $1.7 \pm 0.8$ \\
$\mathbf{1 4 c}$ & $0.7 \pm 0.1$ & $0.6 \pm 0.02$ & $0.5 \pm 0.04$ & $0.5 \pm 0.07$ & $0.6 \pm 0.05$ & $0.6 \pm 0.1$ \\
$\mathbf{1 5 c}$ & & & $0.7 \pm 0.03$ & $0.5 \pm 0.04$ & $0.3 \pm 0.01$ & $0.5 \pm 0.02$
\end{tabular}

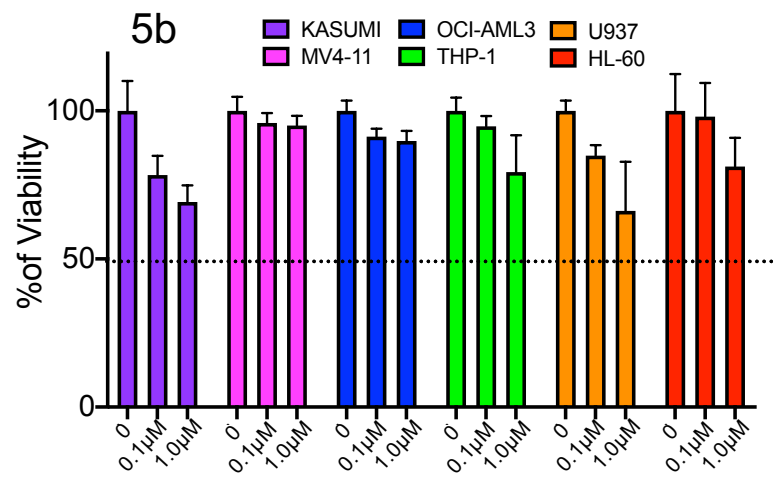

$24 \mathrm{~h}$

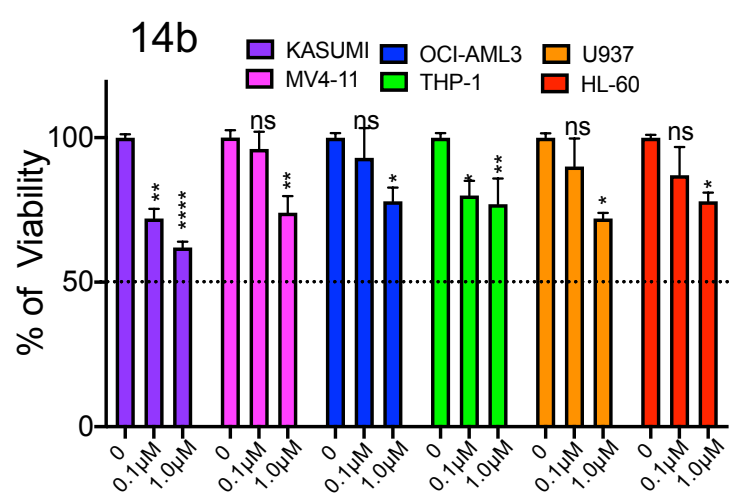

$24 \mathrm{~h}$

Figure 5. Viability upon 24-hour with TCP-derivative carboxamides $5 \mathrm{~b}$ and $14 \mathrm{~b}$ on AML cancer cells at $0.1 \mu \mathrm{M}$ and $1 \mu \mathrm{M}$. Two-way ANOVA analysis corrected with Dunnet's test for multiple comparison revealed a non-significant decrease in cell viability upon $24 \mathrm{~h}$ compared to Non treated (NT, vehicle) upon $5 b$ treatment and a significant decrease in cell viability after treatment with compound $14 \mathrm{~b}\left({ }^{*} p=0.01{ }^{* *} p=0.001{ }^{* \star * \star} p<0.0001\right)$ The results are expressed as percentage of viability compared to controls. Errors bars are mean \pm SEM ( $n=5$ and three technical replicates).

To understand if these effects were specific to the Boc compounds, we prepared the ethyl carbamates $15 \mathrm{~b}$ and $15 \mathrm{c}$, which also exhibited similar levels of antiproliferative activity (Table 3 and Supplementary Figures).<smiles>CC(C)(C)OC(=O)NCc1ccc(C(=O)NCCc2ccccc2)cc1</smiles><smiles>CCOC(=O)NCc1ccc(C(=O)NCCc2ccccc2)cc1</smiles>
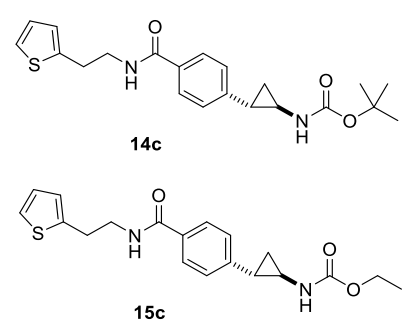

$15 \mathrm{c}$
The carbamates were indistinguishable from the tranylcypromines in their cellular phenotypic effects with a dosedependent increase in $\mathrm{H} 3 \mathrm{~K} 4 \mathrm{me} 2, \mathrm{CD} 86, \mathrm{CD} 11 \mathrm{~b}$ and CD14 (Supplementary figures S2-S8). Some of our compounds were also tested as LSD1 inhibitors against the parasite Schistosoma mansoni, the causative agent of the neglected tropical disease schistosomiasis. In this context as well, the Boc tranylcypromines 14 were more active than the free amines $5 .^{[22]}$ Based on these results, we believe the carbamates are acting as prodrugs that undergo hydrolysis to liberate the active compound intracellularly, and we have observed a similar phenomenon in our sulfonamide series $6 .{ }^{[18]}$ This suggests that derivatization of tranylcypromines is a promising avenue for the improvement of pharmacokinetic properties, as indicated by the faster time course of cancer cell line and parasite inhibition observed with the carbamates. This probably reflects more efficient cell permeability of the carbamates relative to the ionizable amine present in tranylcypromines. 


\section{Conclusion}

We report a series of tranylcypromines containing a paracarboxamide substituent in the phenyl ring. Many of the compounds, including $\mathbf{5 a}$ and $\mathbf{5 b}$ with the relatively simple benzyl and phenethyl substituent respectively, robustly inhibit LSD1 with submicromolar $\mathrm{IC}_{50}$ values and have similar levels of potency in the inhibition of AML cell lines. We demonstrated LSD1 as the cellular target through measurement of increased histone methylation and increased expression of cellular differentiation markers CD86, CD11b and CD14. Interestingly, $t$ butyl and ethyl carbamate derivatives of the tranylcypromines were potent in cellular assays although unable to inhibit LSD1 in vitro, suggesting they act as metabolically labile prodrugs.

\section{Experimental Section}

Chemistry. General procedures. All chemicals were purchased from Sigma Aldrich, Lancaster Synthesis $\mathrm{GmbH}$, Alfa Aesar, and Novabiochem and used without further purification. TLC was used to monitor reactions and performed on aluminium-backed silica gel coated plates (Merck DC, Alufolien Kieselgel $60 \mathrm{~F}_{254}$ ) with spots visualized by UV-light $\left(\begin{array}{lll}\lambda & 254 & \mathrm{~nm}\end{array}\right)$. Product concentration after reactions and extractions involved the use of a rotary evaporator operating at reduced pressure of ca. 20 Torr and the term in vacuo refers to solvent concentration at reduced pressure. When necessary products were purified by flash chromatography using silica gel (MN Kieselgel 60, 40-63 $\mu \mathrm{m}, 230-400$ mesh ASTM). NMR spectra were recorded on a Bruker AC 400 spectrometer and the spectra were calibrated to the residual deuterated solvent peak $\left(\mathrm{CDCl}_{3}, \mathrm{CD}_{3} \mathrm{OD}\right.$ or DMSO- $\left.d_{6}\right)$. The chemical shifts are reported in $\delta(\mathrm{ppm})$ units followed by brackets for protons containing spectral details in this order: multiplicity (s: singlet, d: doublet, $\mathrm{t}$ : triplet, q: quartet, m: multiplet, br: broad), coupling constants (reported in $\mathrm{Hz}$ ), number of protons (from integration). HRMS were acquired through the EPSRC National Mass Spectrometry Service Centre, Swansea. Melting points were determined with a STUART Melting point SMP10. IR spectra were determined with Perkin Elmer, Spectrum GX, FT-IR system. RP-HPLC analyses were performed with an Agilent Technologies 1200 series chromatograph with an Agilent Technologies ZORBAX Eclipse XDB-C18 (5 $\mu \mathrm{m}, 4.6 \times 150 \mathrm{~mm})$ column. Gradient used: 95:5 water: methanol with $0.05 \%$ TFA additive to $5: 95$ water: methanol over 15 min returning to $95: 5$ water: methanol over $5 \mathrm{~min}$ at a flow rate of $1 \mathrm{~mL} / \mathrm{min}$. Purity was monitored at $220 \mathrm{~nm}$ and found to be at least $95 \%$ for all compounds that were tested in biological assays.

Methyl 4-formylbenzoate (8): 4-Formylbenzoic acid (10.0 g, 66.0 mol, 1.0 equiv.) was dissolved in anhydrous $\mathrm{MeOH}(100 \mathrm{~mL})$ with cooling $\left(-5{ }^{\circ} \mathrm{C}\right)$ and acetyl chloride $(24.1 \mathrm{~g},, 21.2 \mathrm{~mL}, 0.33 \mathrm{~mol}, 5.0$ equiv.) was added dropwise over a period of $10 \mathrm{~min}$. After $30 \mathrm{~min}$, the reaction mixture was warmed to $\mathrm{rt}$ and stirred overnight. The volatiles were removed in vacuo and the residue dissolved in EtOAc $(70 \mathrm{~mL})$, washed with $1 \mathrm{~N} \mathrm{NaOH}$, (100 mL x 3) followed by sat. $\mathrm{NaHCO}_{3}(50 \mathrm{~mL} \times 3), \mathrm{H}_{2} \mathrm{O}(50 \mathrm{~mL} \times 3)$ and brine $(50 \mathrm{~mL} \times 3)$. The organic phase was dried over $\mathrm{MgSO}_{4}$, filtered and concentrated to give $8(9.8 \mathrm{~g}, 91 \%)$ as a crystaline white solid that was used without further purification: $R_{f}=0.4$, (Petroleum ether/EtOAc 3:7); mp $180{ }^{\circ} \mathrm{C}$; IR 1716, 1684, $1428 \mathrm{~cm}^{-1}$; ${ }^{1} \mathrm{H}$ NMR $\left(\mathrm{CDCl}_{3}\right) \delta 3.91$ (s, 3H), 7.94 (d, J=8.5 Hz, 2H), 8.19 (d, J=8.3 Hz, 2H), 10.00 (s, 1H); ${ }^{13} \mathrm{C}$ NMR $\left(\mathrm{CDCl}_{3}\right) \delta 52.6,129.6,130.3,135.2,139.3,166.2,191.7$; HRMS (ESI) $\mathrm{m} / \mathrm{z}$ calcd. for $\mathrm{C}_{9} \mathrm{H}_{9} \mathrm{O}_{3}[\mathrm{M}+\mathrm{H}]^{+} 165.0546$, found 165.0545 .

(E)-Methyl 4-(3-(tert-butoxy)-3-oxoprop-1-en-1-yl) benzoate (9): To a solution of KOt-Bu (7.3 g, $64.6 \mathrm{mmol}, 1.1$ equiv.) in dry THF $(100 \mathrm{~mL})$, tert-butyl diethylphosphonoacetate $(16.3 \mathrm{~g}, 15.4 \mathrm{~mL}, 64.6 \mathrm{mmol}, 1.1$ equiv.) was slowly added dropwise at $-5{ }^{\circ} \mathrm{C}$ for a period of $15 \mathrm{~min}$. The mixture was stirred for $1 \mathrm{~h}$ while mantaining the same temperature. Aldehyde 8 (9.8 g, $58.7 \mathrm{mmol}, 1$ equiv.), dissolved in dry THF $(40 \mathrm{~mL})$ was then added dropwise to the mixture with vigorous stirring at $-5{ }^{\circ} \mathrm{C}$ for a period of $20 \mathrm{~min}$. The reaction mixture was warmed to $\mathrm{rt}$ and stirred overnight. After that time, the reaction mixture was poured into iced $\mathrm{H}_{2} \mathrm{O}$ $(100 \mathrm{~mL})$ and extracted with EtOAc $(100 \mathrm{~mL} \times 5)$. The organic phases were combined and washed with sat. $\mathrm{NaHCO}_{3}(100 \mathrm{~mL}), \mathrm{H}_{2} \mathrm{O}(100 \mathrm{~mL})$ and brine $(100 \mathrm{~mL})$ and dried over $\mathrm{MgSO}_{4}$. Evaporation of the solvent in vacuo provided $9(14.9 \mathrm{~g}, 98 \%)$ as a white crystaline solid that was used without further purification: $\mathrm{R}_{f}=0.64$ (Petroleum Ether/ EtOAc 2:8); mp $64{ }^{\circ} \mathrm{C} ;{ }^{1} \mathrm{H} \mathrm{NMR}\left(\mathrm{CDCl}_{3}\right) \delta 1.52(\mathrm{~s}, 9 \mathrm{H}), 3.90(\mathrm{~s}, 3 \mathrm{H}), 6.43(\mathrm{~d}, \mathrm{~J}=16.0 \mathrm{~Hz}$, 1H) 7.53-7.59 (m, 3H), $8.04(\mathrm{~d}, \mathrm{~J}=8.0 \mathrm{~Hz}, 2 \mathrm{H}) .{ }^{13} \mathrm{C} \mathrm{NMR}\left(\mathrm{CDCl}_{3}\right) \delta 28.2$, $52.3,80.9,122.6,127.8,130.1,131.2,139.0,142.1,165.8,166.5$; HRMS (ESI) $\mathrm{m} / \mathrm{z}$ calcd for $\mathrm{C}_{15} \mathrm{H}_{19} \mathrm{O}_{4}[\mathrm{M}+\mathrm{H}]^{+} 263.1278$, found 263.1278 .

(士)-trans-4-Methyl[2-(tert-butoxycarbonyl) cyclopropyl)]benzoate (10): A flame dried flask was charged with potassium tert-butoxide $(0.49 \mathrm{~g}, 4.37$ $\mathrm{mmol}$ ) and trimethylsufoxonium iodide (0.92 $\mathrm{g}, 4.18 \mathrm{mmol})$. DMSO (25 $\mathrm{mL}$ ) was then added. The mixture was stirred under a nitrogen atmosphere for 30 minutes, before the dropwise addition of alkene 9 $(1.00 \mathrm{~g}, 3.81 \mathrm{mmol})$ dissolved in DMSO $(15 \mathrm{~mL})$ over 30 minutes. The reaction mixture was stirred at ambient temperature under a nitrogen atmosphere for $16 \mathrm{~h}$. Water $(50 \mathrm{~mL})$ and EtOAc $(50 \mathrm{~mL})$ were then added and the organic layer separated. The aqueous layer was extracted a further 4 times with EtOAc $(50 \mathrm{~mL})$ and the combined organic extracts dried over MgSO4 and concentrated. Purification by silica gel column chromatography gave 10 as a white solid $(0.56 \mathrm{~g}, 53 \%) . \mathrm{R}_{f}=0.66$ (petroleum ether /EtOAc 8:2); mp $40{ }^{\circ} \mathrm{C}$; IR 1715, $1609 \mathrm{~cm}^{-1} ;{ }^{1} \mathrm{H}$ NMR $\left(\mathrm{CDCl}_{3}, 400 \mathrm{MHz}\right) \delta: 1.26$ (ddd, $\left.J=4.8,6.4,8.5 \mathrm{~Hz}, 1 \mathrm{H}\right), 1.46(\mathrm{~s}, 9 \mathrm{H}), 1.57$ (m, $1 \mathrm{H}$ ), 1.88 (ddd, J=4.4, 5.5, $8.6 \mathrm{~Hz}, 1 \mathrm{H}$ ), 2.4 (ddd, J=4.1, 5.4, $9.5 \mathrm{~Hz}$, $1 \mathrm{H}), 3.9(\mathrm{~s}, 3 \mathrm{H}), 7.1$ (d, J=8.3 Hz, 2H), 7.9 (d, J=8.4 Hz, $2 \mathrm{H}) ;{ }^{13} \mathrm{C}$ NMR $\left(\mathrm{CDCl}_{3}, 100 \mathrm{MHz}\right) \delta 16.5,24.6,24.8,27.1,50.9,79.8,124.9,127.6$, 128.7, 145.07, 165.8, 171.0; HRMS (ESI) m/z calcd. for $\mathrm{C}_{16} \mathrm{H}_{24} \mathrm{O}_{4} \mathrm{~N}$ $\left[\mathrm{M}+\mathrm{NH}_{4}\right]^{+} 294.1700$, found 294.1704 .

(士)-trans-[2-(4-(Methoxycarbonyl)phenyl]cyclopropanecarboxylic acid (11): Trifluoroacetic acid $(19.7 \mathrm{~g}, 13.2 \mathrm{~mL}, 0.17 \mathrm{~mol}, 13$ equiv.) and triethylsilane ( $3.86 \mathrm{~g}, 5.3 \mathrm{~mL}, 33.3 \mathrm{mmol}, 2.5$ equiv.) were added to a solution of $10(3.7 \mathrm{~g}, 13.4 \mathrm{mmol})$ in dichloromethane $(40 \mathrm{~mL})$. The reaction mixture was stirred at $\mathrm{rt}$ and monitored by TLC. After completion, the reaction mixture was co-evaporated with acetonitrile $(15 \mathrm{~mL} \times 3)$ to give $11(2.1 \mathrm{~g}, 72 \%)$ as a white crystalline solid that was used without further purification: $\mathrm{mp} 123{ }^{\circ} \mathrm{C}$; IR $3307,1716,1608,1477 \mathrm{~cm}-1$; ${ }^{1} \mathrm{H}$ NMR $\left(\mathrm{CD}_{3} \mathrm{OD}, 400 \mathrm{MHz}\right) \delta 1.43$ (ddd, J=4.6, 6.5, $8.5 \mathrm{~Hz}, 1 \mathrm{H}$ ), 1.60 (ddd, $J=4.6,5.3,9.4 \mathrm{~Hz}, 1 \mathrm{H}$ ), 1.92 (ddd, $J=4.1,5.4,8.5 \mathrm{~Hz}, 1 \mathrm{H}$ ), 2.51 (ddd $J=4.0,6.3,9.2 \mathrm{~Hz}, 1 \mathrm{H}), 3.90(\mathrm{~s}, 3 \mathrm{H}), 7.25$ (d, J=8.4 Hz, 2H), 7.93 (d, $J=8.44 \mathrm{~Hz}, 2 \mathrm{H}) ;{ }^{13} \mathrm{C}$ NMR $\left(\mathrm{CD}_{3} \mathrm{OD}, 100 \mathrm{MHz}\right.$ ) $\delta$ 17.9, 25.6, 26.9, 52.5, 127.1, 129.4, 130.7, 147.6, 168.7, 176.4; HRMS (ESI) $\mathrm{m} / \mathrm{z}$ calcd. for $\mathrm{C}_{12} \mathrm{H}_{11} \mathrm{O}_{4}[\mathrm{M}-\mathrm{H}]^{-}$219.0663, found 219.0659.

(士)-trans-4-Methyl-2-[(tert-butoxycarbonyl)amino]cyclopropyl benzoate (12): The carboxylic acid 11 (2.1 g, $9.5 \mathrm{mmol}, 1.0$ equiv.), diphenylphosphoryl azide $(2.86 \mathrm{~g}, 2.27 \mathrm{~mL}, 10.5 \mathrm{mmol}, 1.1$ equiv.) and triethylamine $(1.44 \mathrm{~g}, 1.98 \mathrm{~mL}, 14.3 \mathrm{mmol}, 1.5$ equiv.) were combined in tert-butanol $(11 \mathrm{~mL})$ under argon, heated at reflux and allowed to react for $72 \mathrm{~h}$. After that time, the reaction mixture was cooled to rt, diluted with EtOAc $(20 \mathrm{~mL})$ and washed with saturated $\mathrm{Na}_{2} \mathrm{CO}_{3}$ solution $(20 \mathrm{~mL} \times 3)$. The organic layer was separated and the aqueous layer further extracted with EtOAc $(20 \mathrm{~mL})$. The organic layers were combined $(40 \mathrm{~mL})$, washed with sat. $\mathrm{NaHCO}_{3}(10 \mathrm{~mL}), \mathrm{H}_{2} \mathrm{O}(10 \mathrm{~mL})$ and brine $(10 \mathrm{~mL})$ and dried over $\mathrm{MgSO}_{4}$. Concentration in vacuo afforded a yellow oil which was purified by silica gel column chromatography (Hexane/EtOAc 8:2) affording 12

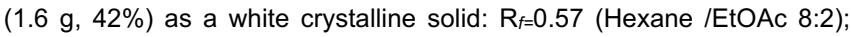
$\mathrm{mp} 45{ }^{\circ} \mathrm{C} ;{ }^{1} \mathrm{H}$ NMR $\left(\mathrm{CDCl}_{3}, 400 \mathrm{MHz}\right) \delta 1.20-1.24(\mathrm{~m}, 2 \mathrm{H}), 1.43(\mathrm{~s}, 9 \mathrm{H})$, 2.07 (td, J=3.1, 7.6 Hz, 1H), 2.70-2.78 (m, 1H) 3.9, (s, 3H), 7.15 (d, J=8.5 $\mathrm{Hz}, 2 \mathrm{H}), 7.9$ (d, J=8.4 Hz, 2H); ${ }^{13} \mathrm{C}$ NMR $\left(\mathrm{CDCl}_{3}, 100 \mathrm{MHz}\right) \delta 14.8,26.3$, 28.0, 28.1, 28.4, 55.3, 113.8, 127.8, 130.6, 132.7, 157.9; 168.7; HRMS (ESI) $\mathrm{m} / \mathrm{z}$ calcd. for $\mathrm{C}_{15} \mathrm{H}_{18} \mathrm{~N}_{1} \mathrm{O}_{4}[\mathrm{M}-\mathrm{H}]^{-} 276.1241$, found 276.1243 . 
(士)-trans-4-2-[(tert-Butoxycarbonyl) amino)cyclopropyl]benzoic acid (13): To a suspension of 12 (1.6 g, $5.7 \mathrm{mmol}, 1$ equiv.) in THF: $\mathrm{H}_{2} \mathrm{O}$ (3:1 ratio), $\mathrm{LiOH}(0.4 \mathrm{~g}, 17.32 \mathrm{mmol}, 3$ equiv.) was added and the reaction mixture heated to $50{ }^{\circ} \mathrm{C}$ and stirred for $3 \mathrm{~h}$. The reaction was monitored by TLC and after completion, the reaction mixture was diluted with water $(10 \mathrm{~mL})$ and acidified to $\mathrm{pH} 1-2$ with sat. $\mathrm{KHSO}_{4}$. The aqueous layer was extracted with EtOAc $(20 \mathrm{~mL} \times 3)$ and the combined organic layers (60 $\mathrm{mL}$ ) were washed with sat. $\mathrm{NaHCO}_{3}(10 \mathrm{~mL}), \mathrm{H}_{2} \mathrm{O}(10 \mathrm{~mL})$ and brine $\mathrm{H}_{2} \mathrm{O}(10 \mathrm{~mL})$ and dried over $\mathrm{MgSO}_{4}$. Solvent concentration in vacuo afforded $13(1.3 \mathrm{~g}, 82 \%)$ as a white solid that was used without further purification. IR 3314, 2873, 1681, $1453 \mathrm{~cm}^{-1} ;{ }^{1} \mathrm{H} \mathrm{NMR}\left(\mathrm{CD}_{3} \mathrm{OD}, 400 \mathrm{MHz}\right)$ $\delta$ 1.21-1.25 (m, 1H), $1.43(\mathrm{~s}, 9 \mathrm{H}), 2.04$ (td, $J=3.9,7.9 \mathrm{~Hz}, 1 \mathrm{H}), 2.69-2.65$ (m, 1H), 7.19 (d, J=8.3 Hz, 2H), $7.91(\mathrm{~d}, J=8.3 \mathrm{~Hz}, 2 \mathrm{H}) ;{ }^{13} \mathrm{C}$ NMR $\left(\mathrm{CD}_{3} \mathrm{OD}, 100 \mathrm{MHz}\right) \delta 17.1,25.8,28.7,35.0,80.3,126.9,129.4,130.7$, 148.5, 158.9, 169.9; HRMS (ESI) $\mathrm{m} / \mathrm{z}$ calcd. for $\mathrm{C}_{17} \mathrm{H}_{25} \mathrm{NO}_{4}[\mathrm{M}+\mathrm{H}]^{+}$ 273.1961, found 273.1962 .

General procedure for 14a-p and 5a-p: To a stirring suspension of 12 in dichloromethane, Hünig's base (2 equiv.) was added and the mixture stirred until obtaining a clear solution. Subsequently, HOBt ( 0.2 equiv.) and $\mathrm{EDCl}$ ( 1.5 equiv.) were added and the reaction mixture stirred for 30 $\mathrm{min}$. The desired amine was added to the mixture and stirring continued at $r$ overnight. After that time, the reaction mixture was diluted with dichloromethane and washed with $2 \mathrm{M} \mathrm{HCl}$ and $1 \mathrm{M} \mathrm{NaOH}$. The organic layers were combined, washed with sat. $\mathrm{NaHCO}_{3}, \mathrm{H}_{2} \mathrm{O}$ and brine and dried over $\mathrm{MgSO}_{4}$. Concentration in vacuo afforded Boc amides 14a-p. Acid hydrolysis to remove the Boc protecting group was carried out by stirring the carbamate in $0.5 \mathrm{~mL}$ of THF and $0.5 \mathrm{~mL}$ of $4 \mathrm{M} \mathrm{HCl}$ in $1,4-$ dioxane at rt overnight. After completion, the reaction mixure was diluted with acetonitrile and concentrated in vacuo afforded to give tranylcypromines 5a-p as their hydrochloride salt. The salts were washed with diethyl ether and purified by preparative RP-HPLC.

tert-Butyl (( \pm trans-2-(4-Phenethylcarbamoyl)phenylcyclopropyl carbamate (14b): Yield: $63 \%$, white solid; IR 3393, 3376, 1701, 1681, $1516 \mathrm{~cm}^{-1} ;{ }^{1} \mathrm{H}$ NMR $(\mathrm{CDCl} 3) \delta 1.17-1.20(\mathrm{~m}, 2 \mathrm{H}), 1.44(\mathrm{~s}, 9 \mathrm{H}), 2.05(\mathrm{td}$, $J=3.0,7.7 \mathrm{~Hz}, 1 \mathrm{H}), 2.68-2.77(\mathrm{~m}, 1 \mathrm{H}), 2.92(\mathrm{t}, J=7.0 \mathrm{~Hz}, 2 \mathrm{H}), 6.73$ (q, $J=7.2 \mathrm{~Hz}, 2 \mathrm{H}), 4.87($ br s, $1 \mathrm{H}), 6.08($ br s, $1 \mathrm{H}), 7.13(\mathrm{~d}, J=8.1 \mathrm{~Hz}, 2 \mathrm{H})$, 7.21-7.24 (m, 3H), 7.39-7.34 (m, 2H), $7.58(\mathrm{~d}, \mathrm{~J}=8.4 \mathrm{~Hz}, 2 \mathrm{H}) ;{ }^{13} \mathrm{C}$ NMR $(\mathrm{CDCl} 3) \delta 16.8,22.1,28.5,33.1,35.8,41.2,80.8,125.39,125.5,125.8$, 127.6, 127,76, 131.21, 137.9, 143.6, 156.7, 166.2; HRMS m/z calcd for $\mathrm{C}_{23} \mathrm{H}_{29} \mathrm{~N}_{2} \mathrm{O}_{3}[\mathrm{M}+\mathrm{H}]+381.2173$, found 381.2173 .

tert-Butyl (( \pm )trans-2-(4-(2-Thiophenylethylcarbamoyl)phenylcyclopropyl carbamate (14c): Yield, $51 \%$, white solid; $\mathrm{mp} 94{ }^{\circ} \mathrm{C}$; IR 3358, 3335, 1685 $1449 \mathrm{~cm}^{-1} ;{ }^{1} \mathrm{H}$ NMR $(\mathrm{CDCl} 3) \delta 1.61-1.19(\mathrm{~m}, 2 \mathrm{H}), 1.43(\mathrm{~s}, 9 \mathrm{H}), 2.02-2.05$ (m, 1H), 2.68-2.76 (m,1H), $3.06(\mathrm{t}, J=6.4 \mathrm{~Hz}, 2 \mathrm{H}), 3.62(\mathrm{q}, \mathrm{J}=6.4 \mathrm{~Hz}, 2 \mathrm{H})$, $4.93(\mathrm{br} \mathrm{s}, 1 \mathrm{H}), 6.33(\mathrm{br} \mathrm{s}, 1 \mathrm{H}), 6.83-6.87(\mathrm{~m}, 1 \mathrm{H}), 6.95(\mathrm{dd}, \mathrm{J}=3.4,4.9 \mathrm{~Hz}$ $1 \mathrm{H}), 7.10-7.16(\mathrm{~m}, 3 \mathrm{H}), 7.61(\mathrm{~d}, \mathrm{~J}=8.3 \mathrm{~Hz}, 2 \mathrm{H}) ;{ }^{13} \mathrm{C}$ NMR (CDCl3) $\delta 15.5$, 23.9, 27.5, 28.9, 31.8, 40.12, 78.6, 122.9, 124.3, 125.3, 125.8, 125.9, 131.0, 140.2, 143.6, 155.1, 166.13; HRMS m/z calcd. for $\mathrm{C}_{21} \mathrm{H}_{27} \mathrm{~N}_{2} \mathrm{O}_{3} \mathrm{~S}$ $[\mathrm{M}+\mathrm{H}]^{+} 387.1737$, found 387.1737 .

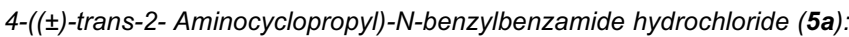
Yield $71 \%$, yellow crystalline solid; $\mathrm{mp} 200{ }^{\circ} \mathrm{C}$; IR 3336, 3289, 3075, $1674,1437 \mathrm{~cm}^{-1} ;{ }^{1} \mathrm{H}$ NMR $\left(\mathrm{CD}_{3} \mathrm{OD}\right) \delta 1.36-1.42(\mathrm{~m}, 1 \mathrm{H}), 1.46-1.51(\mathrm{~m}$, $1 \mathrm{H}), 2.46$ (ddd, J=3.3, 6.6, $9.9 \mathrm{~Hz}, 1 \mathrm{H}), 2.90-2.92,(\mathrm{~m}, 1 \mathrm{H}), 4.6(\mathrm{~s}, 2 \mathrm{H})$, 7.11-7.19 (m, 3H), 7.22-7.35 (m, 4H), $7.81(\mathrm{~d}, \mathrm{~J}=8.2 \mathrm{~Hz}, 2 \mathrm{H}) ;{ }^{13} \mathrm{C}$ NMR $\left(\mathrm{CD}_{3} \mathrm{OD}\right) \delta 14.3,22.4,32.2,44.4,127.5,128.2,128.5,129.7,129.5$, 134.1, 140.2, 143.9, 169.6; HRMS (ESI) $\mathrm{m} / \mathrm{z}$ calcd. for $\mathrm{C}_{17} \mathrm{H}_{19} \mathrm{~N}_{2} \mathrm{O}_{1}$ $[\mathrm{M}+\mathrm{H}]^{+}$267.1492, found 267.1495.

4-( \pm -trans -2-Aminocyclopropyl)-N-phenethylbenzamide hydrochloride (5b): Yield $67 \%$, yellow solid; $\mathrm{mp} 180{ }^{\circ} \mathrm{C}$; IR $3283,1637,1545 \mathrm{~cm}^{-1}$; ${ }^{1} \mathrm{HNMR}\left(\mathrm{CD}_{3} \mathrm{OD}\right) \delta$ 1.36-1.42 (m, 1H), 1.48 (ddd, $\left.J=4.2,6.7,10.31 \mathrm{H}\right)$, 2.42 (ddd, J=3.5, $6.3 \mathrm{~Hz}, 10.3 \mathrm{1H}$ ), 2.90 (t, $J=7.7 \mathrm{~Hz}, 3 \mathrm{H}), 3.58$ (t, J=7.2 $\mathrm{Hz}, 2 \mathrm{H}), 7.17-7.20(\mathrm{~m}, 1 \mathrm{H}), 7.24-7.29(\mathrm{~m}, 6 \mathrm{H}) 7.72(\mathrm{~d}, \mathrm{~J}=7.7 \mathrm{~Hz}, 2 \mathrm{H})$; ${ }^{13} \mathrm{CNMR}\left(\mathrm{CD}_{3} \mathrm{OD}\right) \delta 14.3,22.4,32.3,36.3,42.6,127.3,127.4,128.6$,
129.5, 129.9, 134.3, 140.6, 143.8, 169.7; HRMS (ESI) $\mathrm{m} / \mathrm{z}$ calcd. for $\mathrm{C}_{18} \mathrm{H}_{21} \mathrm{~N}_{2} \mathrm{O}[\mathrm{M}+\mathrm{H}]^{+}$281.1648, found 281.1648.

4-( \pm -trans $\quad$-2-Aminocyclopropyl)-N-(2-(thiophen-2-yl)ethyl)benzamide hydrochloride (5c): Yield $47 \%$, yellow solid; $\mathrm{mp} 218{ }^{\circ} \mathrm{C}$; IR 3318, 2775 , 2977, 1626, $1505 \mathrm{~cm}^{-1} ;{ }^{1} \mathrm{H}$ NMR (CD $\left.{ }_{3} \mathrm{OD}\right) \delta 1.37-1.42(\mathrm{~m}, 1 \mathrm{H}), 1.48$ (ddd, $J=4.56,6.7,10.2 \mathrm{~Hz}, 1 \mathrm{H}$ ), 2.43 (ddd, $J=3.6,6.0,9.0 \mathrm{~Hz}, 1 \mathrm{H}$ ), 2.90-2.94 (m, 1H), 3.13 (t, J=7.0 Hz, 2H), 3.61 (t, $J=7.0 \mathrm{~Hz}, 2 \mathrm{H}$ ), 6.88 (dd, J=1.0, $3.4 \mathrm{~Hz}, 1 \mathrm{H}), 6.91-6.94(\mathrm{~m}, 1 \mathrm{H}) 7.20(\mathrm{dd}, J=1.0,4.8 \mathrm{~Hz}, 1 \mathrm{H}), 7.25(\mathrm{~d}$, $J=8.4 \mathrm{~Hz}, 2 \mathrm{H}), 7.75(\mathrm{~d}, \mathrm{~J}=8.4 \mathrm{~Hz}, 2 \mathrm{H}) ;{ }^{13} \mathrm{C}$ NMR $\left(\mathrm{CD}_{3} \mathrm{OD}\right) \delta 14.3,22.4$, $30.1,32.2,42.7,124.7,126.3,127.4,127.8,128.6,134.1,142.5,143.7$, 169.7 .

4-( \pm -trans-2-Aminocyclopropyl)-N-(cyclohexylmethyl)benzamide hydrochloride (5d): Yield 58\%, yellow solid; $\mathrm{mp} 198{ }^{\circ} \mathrm{C}$; IR 3335, 1712, 1696, $1459 \mathrm{~cm}^{-1} ;{ }^{1} \mathrm{H}$ NMR (CD $\left.3 \mathrm{OD}, 400 \mathrm{MHz}\right), \delta 0.94-1.03(\mathrm{~m}, 2 \mathrm{H}), 1.18-$ $1.31(\mathrm{~m}, 4 \mathrm{H}), 1.33-1.44(\mathrm{~m}, 1 \mathrm{H}), 1.48-1.52(\mathrm{~m}, 1 \mathrm{H}), 1.58-1.69(\mathrm{~m}, 2 \mathrm{H})$, 1.71-1.82 (m, 3H), 2.41-2.49 (m, 1H), 2.88-2.92 (m, 1H) $3.20(\mathrm{~d}, J=6.9$ $\mathrm{Hz}, 2 \mathrm{H}), 7.26$ (d, J=8.2 Hz, 2H), $7.76(\mathrm{~d}, \mathrm{~J}=8.2 \mathrm{~Hz}, 2 \mathrm{H}) ;{ }^{13} \mathrm{C} \mathrm{NMR}$ $\left(\mathrm{CD}_{3} \mathrm{OD}, 100 \mathrm{MHz}\right) \delta 14.3,22.4,26.9,27.6,32.3,39.2,39.4,47.2,127.4$, 128.6, 134.3, 143.6, 169.8; HRMS (ESI) $\mathrm{m} / \mathrm{z}$ calcd. for $\mathrm{C}_{17} \mathrm{H}_{25} \mathrm{~N}_{2} \mathrm{O}[\mathrm{M}+\mathrm{H}]^{+}$, 273.1961 , found 273.1962 .

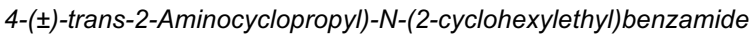
hydrochloride (5e): Yield $33 \%$, yellow solid; $\mathrm{mp} 79{ }^{\circ} \mathrm{C}$; IR 3318, 1632 , 1539, $1449 \mathrm{~cm}^{-1}$; ${ }^{1} \mathrm{HNMR}$ (DMSO-d6, $400 \mathrm{MHz}$ ) $\delta$ 0.84-0.96 (m, 2H), 1.08-1.31 (m, 5H), 1.36-1.44 (m, 2H), 1.45-1.51 (m, 1H), 1.64-1.80 (m, $5 \mathrm{H}), 2.43$ (ddd, J=3.5, 5.5, $10.1 \mathrm{~Hz}, 1 \mathrm{H}), 2.81-2.89(\mathrm{~m}, 1 \mathrm{H}), 3.22-3.29(\mathrm{~m}$, $2 \mathrm{H}), 7.25(\mathrm{~d}, J=8.3 \mathrm{~Hz}, 2 \mathrm{H}), 7.75(\mathrm{~d}, J=8.3 \mathrm{~Hz}, 2 \mathrm{H}), 8.39(\mathrm{t}, J=6.0 \mathrm{~Hz}, 1 \mathrm{H})$, 8.64 (br s, 2H); ${ }^{13} \mathrm{CNMR}\left(\mathrm{CD}_{3} \mathrm{OD}, 100 \mathrm{MHz}\right) \delta 14.3,22.4,27.4,27.6$, 32.2, 34.3, 36.8, 37.9, 38.8, 127.4, 128.6, 134.3, 143.6, 169.6; HRMS (ESI) $\mathrm{m} / \mathrm{z}$ calcd. for $\mathrm{C}_{18} \mathrm{H}_{27} \mathrm{~N}_{2} \mathrm{O}[\mathrm{M}+\mathrm{H}]^{+} 287.2118$, found 287.2119.

4-(( \pm -trans-2-Aminocyclopropyl)-N-(4-fluorobenzyl)benzamide hydrochloride (5f): Yield $45 \%$, yellow solid; mp $98{ }^{\circ} \mathrm{C}$; IR 335, 2486, 1620 , 1516, $1458 \mathrm{~cm}^{-1} ;{ }^{1} \mathrm{H}$ NMR $\left(\mathrm{CD}_{3} \mathrm{OD}, 400 \mathrm{MHz}\right) \delta 1.37-1.42(\mathrm{~m}, 1 \mathrm{H}), 1.49$ (ddd, J=4.7, 7.0, 10.2 Hz, 1H), 2.43 (ddd, J=3.6, 6.5, $10.0 \mathrm{~Hz}, 1 \mathrm{H}$ ), $2.89-$ $2.96(\mathrm{~m}, 1 \mathrm{H}), 4.53,(\mathrm{~s}, 2 \mathrm{H}), 7.0(\mathrm{t}, J=8.7 \mathrm{~Hz}, 2 \mathrm{H}), 7.26(\mathrm{~d}, J=8.2,2 \mathrm{H})$, $7.36(\mathrm{~m}, 2 \mathrm{H}), 7.81(\mathrm{~d}, \mathrm{~J}=8.3 \mathrm{~Hz}, 2 \mathrm{H}) ;{ }^{13} \mathrm{C} \mathrm{NMR}\left(\mathrm{CD}_{3} \mathrm{OD}, 100 \mathrm{MHz}\right) \delta 14.3$, 22.4, 32.3, 43.8, 116.2, 127.5, 128.5, 130.4, 133.9, 136.3, 143.9, 163.5 (d, $J_{F-C}=220 \mathrm{~Hz}$ ), 169.6; HRMS (ESI) $\mathrm{m} / \mathrm{z}$ calcd. for $\mathrm{C}_{17} \mathrm{H}_{18} \mathrm{~F}_{1} \mathrm{~N}_{2} \mathrm{O}[\mathrm{M}+\mathrm{H}]^{+}$ 285.1398 , found 285.1402 .

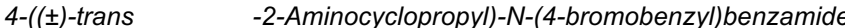
hydrochloride (5g): Yield $65 \%$, white solid; $\mathrm{mp} 97^{\circ} \mathrm{C}$; IR 3320, 3035 , 2665, 1637, 1533, $14893 \mathrm{~cm}^{-1}$; ${ }^{1} \mathrm{HNMR}\left(\mathrm{CD}_{3} \mathrm{OD}, 400 \mathrm{MHz}\right) \delta 1.37-1.42$ (m, 1H), 1.46-1.51 (m, 1H), 2.44 (ddd, $J=3.2,6.3,9.7 \mathrm{~Hz}, 1 \mathrm{H}$ ), 2.90-2.93 (m, 1H), $4.52(\mathrm{~s}, 2 \mathrm{H}), 7.26(\mathrm{~d}, \mathrm{~J}=8.0 \mathrm{~Hz}, 4 \mathrm{H}), 7.47(\mathrm{~d}, \mathrm{~J}=8.3 \mathrm{~Hz}, 2 \mathrm{H}), 7.83$ (d, $J=8.3 \mathrm{~Hz}, 2 \mathrm{H}) ;{ }^{13} \mathrm{CNMR}\left(\mathrm{CD}_{3} \mathrm{OD}, 100 \mathrm{MHz}\right) \delta 14.4,22.4,32.3,43.9$, 121.8, 127.5, 128.8, 130.5, 132.6, 133.9, 139.6, 144.00, 169.7; HRMS (ESI) $\mathrm{m} / \mathrm{z}$ calcd. for $\mathrm{C}_{17} \mathrm{H}_{18} \mathrm{BrN}_{2} \mathrm{O}[\mathrm{M}+\mathrm{H}]^{+} 345.0597$, found 345.0602 .

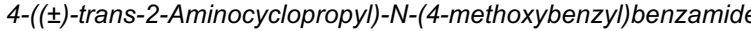
hydrochloride (5h): Yield 52\%, yellow solid; mp $123{ }^{\circ} \mathrm{C}$; IR 3364, 1672 , $1528 \mathrm{~cm}^{-1}$; ${ }^{1} \mathrm{HNMR}\left(\mathrm{CD}_{3} \mathrm{OD}, 400 \mathrm{MHz}\right) \delta 1.36-1.41(\mathrm{~m}, 1 \mathrm{H}), 1.49$ (ddd, $J=4.6,6.7,10.5 \mathrm{~Hz}, 1 \mathrm{H}$ ), 2.44 (ddd, $J=3.4,6.3,9.8 \mathrm{~Hz}, 1 \mathrm{H}$ ), 2.91, (ddd, $J=4.0,7.9,11.7 \mathrm{~Hz}, 1 \mathrm{H}), 3.76(\mathrm{~s}, 3 \mathrm{H}), 4.48(\mathrm{~s}, 2 \mathrm{H}), 6.87(\mathrm{~d}, J=8.6 \mathrm{~Hz}$, $2 \mathrm{H}), 7.25$ (d, $J=8.4 \mathrm{~Hz}, 2 \mathrm{H}), 7.26(\mathrm{~d}, J=8.4 \mathrm{~Hz}, 2 \mathrm{H}), 7.79(\mathrm{~d}, J=8.1 \mathrm{~Hz}$, $2 \mathrm{H}) ;{ }^{13} \mathrm{CNMR}\left(\mathrm{CD}_{3} \mathrm{OD}, 100 \mathrm{MHz}\right) \delta 14.3,22.4,32.3,43.9,55.7,114.9$, $127.5,128.7,129.8,132.2,134.1,143.9,160.4,169.5$; HRMS (ESI) $\mathrm{m} / \mathrm{z}$ calcd. for $\mathrm{C}_{18} \mathrm{H}_{21} \mathrm{~N}_{2} \mathrm{O}_{2}[\mathrm{M}+\mathrm{H}]^{+}$297.1598, found 297.1595.

$\mathrm{N}-\left(\left[1,1^{\prime}-\right.\right.$ Biphenyl]-4-ylmethyl)-4- $\quad( \pm \quad$ trans $\quad-2 \quad$-aminocyclopropyl) benzamide hydrochloride (5i): Yield 34\%, yellow solid; IR 3402, 3045 $1715,1632,1540 \mathrm{~cm}^{-1} ; 1 \mathrm{H}$ NMR ( $\left.\mathrm{CD}_{3} \mathrm{OD}, 400 \mathrm{MHz}\right) \delta 1.38-1.43(\mathrm{~m}, 1 \mathrm{H})$, 1.46-1.50 (m, 1H), 2.43 (ddd, J=3.5, 6.3, $10.2 \mathrm{~Hz}, 1 \mathrm{H}$ ), 2.92 (ddd, $J=3.7$ 7.9, $11.6 \mathrm{~Hz}, 1 \mathrm{H}), 4.61(\mathrm{~s}, 2 \mathrm{H}), 7.26-7.29(\mathrm{~m}, 2 \mathrm{H}), 7.30-7.34(\mathrm{~m}, 1 \mathrm{H})$, 7.39-7.45 (m, 4H), 7.56-7.60 (m, 4H), $7.83(\mathrm{~d}, \mathrm{~J}=8.4 \mathrm{~Hz}, 2 \mathrm{H}) ;{ }^{13} \mathrm{C}$ NMR 
$\left(\mathrm{CD}_{3} \mathrm{OD}, 100 \mathrm{MHz}\right) \delta 14.3,22.4,32.2,44.1,127.4,127.8,128.0,128.2$ $128.7,128.9,129.7,134.0,139.2,141.3,142.0,143.8,169.6$.

4-(土)-trans-2-Aminocyclopropyl)- $N, N$-dibenzylbenzamide hydrochloride (5j): Yield 52\%, yellow solid; IR 3214, 1645.7, 1620, $1452 \mathrm{~cm}^{-1} ;{ }^{1} \mathrm{HNMR}$ $\left(\mathrm{CD}_{3} \mathrm{OD}, 400 \mathrm{MHz}\right) \delta 1.37-1.38(\mathrm{~m}, 1 \mathrm{H}), 1.49-1.56(\mathrm{~m}, 1 \mathrm{H}), 2.43$ (ddd $J=3.2,6.4,9.8 \mathrm{~Hz}, 1 \mathrm{H}), 2.96-2.90(\mathrm{~m}, 1 \mathrm{H}), 4.43(\mathrm{br} \mathrm{s}, 2 \mathrm{H}), 4.66(\mathrm{br} \mathrm{s}, 2 \mathrm{H})$ 7.12 (br s, 2H), 7.24-7.30 (m, 7H), 7.32-7.39 (m, 5H), 7.43-7.50 (m, 2H); ${ }^{13} \mathrm{CNMR}\left(\mathrm{CD}_{3} \mathrm{OD}, 100 \mathrm{MHz}\right) \delta 14.1,22.3,32.3,53.7,127.6,128.0,128.2$ 128.7, 129.8, 129.9, 135.5, 142.2, 174.2; HRMS (ESI) $\mathrm{m} / \mathrm{z}$ calcd. for $\mathrm{C}_{24} \mathrm{H}_{25} \mathrm{~N}_{2} \mathrm{O}_{1}[\mathrm{M}+\mathrm{H}]^{+}, 357.1961$, found 357.1960 .

4-(( \pm -trans $\quad$-2-Aminocyclopropyl)phenyl)4-(pyridin-2-yl)piperazin-1yl)methanone hydrochloride (5k): Yield 13\%, orange oil; IR 3358, 1603, 1545, $1435 \mathrm{~cm}^{-1}$; ${ }^{1} \mathrm{HNMR}$ (CD $\left.{ }_{3} \mathrm{OD}, 400 \mathrm{MHz}\right) \delta 1.37-1.43(\mathrm{~m}, 1 \mathrm{H}), 1.51$ (ddd, J=4.4, 6.6, $11.1 \mathrm{~Hz}, 1 \mathrm{H}$ ), 2.48 (ddd, J=3.5, 6.3, $10.0 \mathrm{~Hz}, 1 \mathrm{H}$ ), 2.93 (ddd, J=4.4, 7.6, 11.2 Hz, 1H), 3.8 (br s, 8H), $7.06(\mathrm{t}, J=6.5 \mathrm{~Hz}, 1 \mathrm{H}), 7.32$ (d, J=8.0 Hz, 2H), 7.42 (d, J=9.2 Hz, 1H), 7.48 (d, J=8.0 Hz, 2H), 8.0 (dd, $J=1.24,7.9 \mathrm{~Hz}, 1 \mathrm{H}), 8.05(\mathrm{dt}, J=1.6,8.5 \mathrm{~Hz}, 1 \mathrm{H}) ;{ }^{13} \mathrm{CNMR}\left(\mathrm{CD}_{3} \mathrm{OD}, 100\right.$ $\mathrm{MHz}) \delta 14.3,22.4,32.2,44.8,47.2,114.3,127.8,128.8,131.1,134.5$, 137.5, 142.8, 145.7, 153.7, 172.6; HRMS (ESI) $\mathrm{m} / \mathrm{z}$ calcd. for $\mathrm{C}_{19} \mathrm{H}_{23} \mathrm{~N}_{4} \mathrm{O}$ $[\mathrm{M}+\mathrm{H}]^{+}$323.1866, found 323.1869.

4-(士)-trans-2-Aminocyclopropyl-phenyl)-(4-(pyrimidin-2-yl)piperazin-1yl)methanone hydrochloride (5I): Yield $22 \%$, red oil; IR 3353,1678, 1632, $1551 \mathrm{~cm}^{-1} ;{ }^{1} \mathrm{H}$ NMR (CD $\left.3 \mathrm{OD}, 400 \mathrm{MHz}\right) \delta$ 1.39-1.45 (m, 1H), 1.47 (ddd, $J=4.5,6.9,10.1 \mathrm{~Hz}, 1 \mathrm{H}$ ), 2.44 (ddd, J=3.6, 6.4, $10.2 \mathrm{~Hz}, 1 \mathrm{H}$ ), 2.92-2.96 (m, 1H), 3.53 (br s, 2H), 3.82 (br s, 4H), 3.94 (br s, 2H), 6.66 (t, J=4.7, Hz, $1 \mathrm{H}), 7.29$ (d, J=8.2 Hz, 2H), 7.42 (d, J=8.3 Hz, 2H), 8.35 (d, J=4.8 Hz, $2 \mathrm{H}) ;{ }^{13} \mathrm{C}$ NMR $\left(\mathrm{CD}_{3} \mathrm{OD}, 100 \mathrm{MHz}\right) \delta 14.2,22.4,32.1,40.4,41.7,111.8$, 127.7, 128.6, 135.2, 142.3, 159.1, 162.8, 172.45; HRMS (ESI) $\mathrm{m} / \mathrm{z}$ calcd. for $\mathrm{C}_{18} \mathrm{H}_{22} \mathrm{~N}_{5} \mathrm{O}[\mathrm{M}+\mathrm{H}]^{+} 324.1819$, found 324.1824 .

4-(( \pm -trans-2-Aminocyclopropyl)phenyl)(4-(phenylsulfonyl) piperazin-1yl)methanone hydrochloride (5m): Yield 25\%, white solid; IR 3392, 1637, 1652, $1551 \mathrm{~cm}^{-1} ;{ }^{1} \mathrm{H}$ NMR (CD $\left.{ }_{3} \mathrm{OD}, 400 \mathrm{MHz}\right) \delta 1.33-1.38(\mathrm{~m}, 1 \mathrm{H}), 1.45-$ $1.50(\mathrm{~m}, 1 \mathrm{H}), 2.41-2.43(\mathrm{~m}, 1 \mathrm{H}), 2.45(\mathrm{~s}, 3 \mathrm{H}), 2.87-2.89(\mathrm{~m}, 1 \mathrm{H}), 3.00(\mathrm{br}$ s, 4H), 3.56 (br s, 2H), 3.77 (br s, $2 \mathrm{H}), 7.22(\mathrm{~d}, \mathrm{~J}=7.6 \mathrm{~Hz}, 2 \mathrm{H}), 7.30$, (d, $J=7.6 \mathrm{~Hz}, 2 \mathrm{H}), 7.44(\mathrm{~d}, J=7.8 \mathrm{~Hz}, 2 \mathrm{H}), 7.65(\mathrm{~d}, J=7.9 \mathrm{~Hz}, 2 \mathrm{H}) ;{ }^{13} \mathrm{C}$ NMR $\left(\mathrm{CD}_{3} \mathrm{OD}, 200 \mathrm{MHz}\right) \delta 14.2,21.5,22.3,32.2,44.2,47.2,127.7,128.6$, $128.9,130.9,133.8,134.5,142.4,145.6,172.2$; HRMS (ESI) $\mathrm{m} / \mathrm{z}$ calcd. for $\mathrm{C}_{21} \mathrm{H}_{26} \mathrm{~N}_{3} \mathrm{O}_{3} \mathrm{~S}[\mathrm{M}+\mathrm{H}]^{+} 400.1689$, found 400.1687 .

4-( \pm )-trans-2-Aminocyclopropyl)phenyl(4-(methylsulfonyl)piperazin-1yl)methanone hydrochloride (5n): Yield 37\%, white solid; IR 3387, 1614, $1562 \mathrm{~cm}^{-1}$; ${ }^{1} \mathrm{HNMR}\left(\mathrm{CD}_{3} \mathrm{OD}, 400 \mathrm{MHz}\right) \delta$ 1.37-1.42 (m, 1H), 1.47 (ddd, $J=4.5,6.8,10.3 \mathrm{~Hz}, 1 \mathrm{H}$ ), 2.42 (ddd, J=3.6, 6.6, $10.2 \mathrm{~Hz}, 1 \mathrm{H}), 2.87$ (s, 3H) 2.89-2.93 (m, 1H), 3.26 (br s, 4H), 3.57 (br s, 2H), 3.8, (br s, 2H), 7.28 (d, $J=8.2 \mathrm{~Hz}, 2 \mathrm{H}), 7.41(\mathrm{~d}, \mathrm{~J}=8.3 \mathrm{~Hz}, 2 \mathrm{H}) ;{ }^{13} \mathrm{CNMR}\left(\mathrm{CD}_{3} \mathrm{OD}, 100 \mathrm{MHz}\right) \delta$ $14.2,22.4,32.0,34.8,46.7,68.0,127.8,128.6,134.7,142.4,172.3$; HRMS (ESI) $m / z$ calcd for $\mathrm{C}_{15} \mathrm{H}_{24} \mathrm{~N}_{3} \mathrm{O}_{3} \mathrm{~S}[\mathrm{M}+\mathrm{H}]+324.1380$, found 324.1380 .

4-(( \pm -trans-2-Aminocyclopropyl) phenyl)4-(2-fluorophenyl)piperazin-1yl)methanone hydrochloride (5o): Yield 44\%, yellow solid; IR 3387, 1603, $1505,1470 \mathrm{~cm}^{-1} ;{ }^{1} \mathrm{H}$ NMR (CD $\left.{ }_{3} \mathrm{OD}, 400 \mathrm{MHz}\right) \delta 1.37-1.42(\mathrm{~m}, 1 \mathrm{H}), 1.44-$ $1.49(\mathrm{~m}, 1 \mathrm{H}), 2.42$ (ddd, J=3.2, 6.3, $9.7 \mathrm{~Hz}, 1 \mathrm{H}), 2.89-2.93(\mathrm{~m}, 1 \mathrm{H}), 3.16$ (br s, 4H), 3.66 (br s 2H), 3.94 (br s 2H), 7.03-7.13 (m, 4H), $7.28(\mathrm{~d}$, $J=7.6 \mathrm{~Hz}, 2 \mathrm{H}), 7.42(\mathrm{~d}, J=7.8 \mathrm{~Hz}, 2 \mathrm{H}) ;{ }^{13} \mathrm{C} \mathrm{NMR}\left(\mathrm{CD}_{3} \mathrm{OD}, 100 \mathrm{MHz}\right) \delta$ $14.5,22.4,32.4,54.9,68.0,117.7,122.3,126.6,127.9,128.4,128.9$, 134.3, 135.9, 142.6, 156.6 (d, JF-C=245.8 Hz), 172.19; HRMS (ESI) $\mathrm{m} / \mathrm{z}$ calcd. for $\mathrm{C}_{20} \mathrm{H}_{23} \mathrm{~F}_{1} \mathrm{~N}_{3} \mathrm{O}[\mathrm{M}+\mathrm{H}]^{+} 340.1820$, found 340.1821 .

2-(4-(4-(士)-trans-2-Aminocyclopropyl)benzoyl)piperazin-1-yl)benzonitrile hydrochloride (5p): Yield 39\%, white solid; IR 3353, 2856, 2221, 1632, $1562 \mathrm{~cm}^{-1}$; ${ }^{1} \mathrm{H}$ NMR (CD $\left.3 \mathrm{OD}, 400 \mathrm{MHz}\right) \delta$ 1.38-1.42 (m, 1H), 1.44-1.51 (m, $1 \mathrm{H}), 2.40-2.45(\mathrm{~m}, 1 \mathrm{H}), 2.92$ (ddd, $J=4.2,8.0,11.0 \mathrm{~Hz}, 1 \mathrm{H}), 3.18$ (br s $2 \mathrm{H}), 3.56-3.59(\mathrm{~m}, 1 \mathrm{H}), 3.64-3.68(\mathrm{~m}, 3 \mathrm{H}), 3.71-3.74(\mathrm{~m}, 2 \mathrm{H}), 3.95$ (br s,
$1 \mathrm{H}), 7.14(\mathrm{t}, J=7.4 \mathrm{~Hz}, 1 \mathrm{H}), 7.19(\mathrm{~d}, J=8.2 \mathrm{~Hz}, 1 \mathrm{H}), 7.29(\mathrm{~d}, J=8.0 \mathrm{~Hz}, 2 \mathrm{H})$, $7.43(\mathrm{~d}, J=8.0 \mathrm{~Hz}, 2 \mathrm{H}), 7.57-7.61(\mathrm{~m}, 1 \mathrm{H}), 7.65(\mathrm{dd}, J=2.07,9.06 \mathrm{~Hz}, 1 \mathrm{H})$; ${ }^{13} \mathrm{C}$ NMR (CD $\left.{ }_{3} \mathrm{OD}, 100 \mathrm{MHz}\right) \delta 14.2,22.4,32.2,43.7,62.2,107.7,119.1$, 120.6, 124.0, 127.7, 128.7, 135.1, 135.3, 135.4, 142.3, 156.6, 172.3; HRMS (ESI) $m / z$ calcd. for $\mathrm{C}_{21} \mathrm{H}_{23} \mathrm{~N}_{4} \mathrm{O}[\mathrm{M}+\mathrm{H}]^{+}, 347.1866$, found 347.1869.

General procedure for $\mathbf{1 5 b}$ and 15c: These carbamates were prepared from 11 by carrying out the Curtius rearrangement in the presence of ethanol to give the ethyl carbamate. The methyl ester was then deprotected and the acid coupled with 2-phenethylamine or 2thiophenethylamine to give $15 \mathrm{~b}$ and $15 \mathrm{c}$ respectively

Ethyl (( \pm trans-2-(4-Phenethylcarbamoyl)phenylcyclopropyl carbamate (15b): Yield 54\%, white solid; IR 3312, 3191, 1689, 1637, 1545, $1510 \mathrm{~cm}^{-}$ 1; ${ }^{1} \mathrm{H}$ NMR $\left(\mathrm{CDCl}_{3}\right) \delta 1.20-1.27(\mathrm{~m}, 5 \mathrm{H}), 2.07-2.11(\mathrm{~m}, 1 \mathrm{H}), 2.72-2.76(\mathrm{~m}$ $1 \mathrm{H}), 2.92$ (t, J=6.9 Hz, 2H), 3.69 (q, J=6.9, Hz, 2H), 4.12 (q, J=6.9 Hz, $2 \mathrm{H}), 7.14$ (d, J=7.9 Hz, 2H), 7.19-7.24 (m, 3H), 7.28-7.34 (m, 2H), 7.58 (d, $\mathrm{J}=7.8 \mathrm{~Hz}, 2 \mathrm{H}) ;{ }^{13} \mathrm{C} \mathrm{NMR}\left(\mathrm{CDCl}_{3}\right) \delta 14.6,16.4,25.2,33.1,35.7,41.1,61.0$, 126.6, 126.7, 126.9, 128.7, 128.8, 132.4, 138.8, 144.4, 157.1, 167.2; HRMS m/z calcd. for $\mathrm{C}_{21} \mathrm{H}_{25} \mathrm{~N}_{2} \mathrm{O}_{3}[\mathrm{M}+\mathrm{H}]^{+} 353.1860$, found 353.1860 .

Ethyl (( \pm trans-2-(4-(2-Thiophenethylcarbamoyl)phenylcyclopropyl carbamate (15c): Yield 49\%, white solid; IR 3318, 3214, 1689, 1655, $1551,1510 \mathrm{~cm}^{-1} ;{ }^{1} \mathrm{H}$ NMR $\left(\mathrm{CDCl}_{3}\right) \delta 1.20-1.23(\mathrm{~m}, 5 \mathrm{H}), 2.06-2.10(\mathrm{~m}, 1 \mathrm{H})$, 2.70-2.74 (m, 1H), $3.13(\mathrm{t}, \mathrm{J}=6.5 \mathrm{~Hz}, 2 \mathrm{H}), 3.69(\mathrm{q}, \mathrm{J}=7.04 \mathrm{~Hz}, 2 \mathrm{H}), 4.11$ (q, J=6.5 Hz, 2H), 6.85 (dd, J=0.9, 3.3 Hz, 1H), 6.94 (dd, J=3.4, $5.1 \mathrm{~Hz}$, $1 \mathrm{H}), 7.13-7.17(\mathrm{~m}, 3 \mathrm{H}), 7.61(\mathrm{~d}, \mathrm{~J}=8.1 \mathrm{~Hz}, 2 \mathrm{H}) ;{ }^{13} \mathrm{C} \mathrm{NMR}\left(\mathrm{CDCl}_{3}\right) \delta 14.6$, $16.4,25.2$, 29.9, 33.1, 41.3, 61.0, 124.1, 125.5, 126.6, 127.0, 127.1, 132.3, 141.3, 141.5, 157.1, 167.2; HRMS m/z calcd. $\mathrm{C}_{19} \mathrm{H}_{23} \mathrm{~N}_{2} \mathrm{O}_{3} \mathrm{~S}[\mathrm{M}+\mathrm{H}]^{+}$ 359.1424 , found 359.1425

\section{Biology.}

LSD1 enzyme assay: LSD1 residual activity after incubation with the carboxamide TCP-derivatives was measured according to our previously reported assay. ${ }^{[19]}$

$A M L$ cell line viability assay: To measure the in vitro compound activity, $100 \mu \mathrm{L}$ of cell suspension was plated out at a density of $2.5 \times 10^{4}$ cells $/ \mathrm{mL}$ in 96 well plates. Tested compounds (stock $250 \mathrm{mM}$ ) were dissolved to the appropriate concentration in RPMI complete medium (10x final concentration) and $10 \mu \mathrm{L}$ of each concentration was immediately added to the plated cell suspension. Each concentration was assessed five times. After treatment, cells were further cultured for the reported amount of time. Cell viability was measured with CellTiter-Glo ${ }$ (Promega, Southampton, UK) by adding $100 \mu \mathrm{L}$ of the reagent to each well. After 10 min of incubation at $\mathrm{RT}, 100 \mu \mathrm{L}$ of cell suspension + reagent were transferred into a white GREINER 96 well plate to eliminate straight light and bioluminescence was recorded in a BMG Cell star microplate reader. Collected raw data were normalised to control (vehicle control) and IC 50 's and statistical significance were determined with GraphPad Prism software (San Diego, CA).

Washout experiment: In a 96 well plate, $100 \mu \mathrm{L}$ suspension of the cell lines THP-1, HL-60, MV4-11, KASUMI, OCI-AML3, U937 were plated at a density of $5 \times 104$ cells $/ \mathrm{mL}$ and treated with $10 \mu \mathrm{L}$ of LSD1 inhibitors (200 nM final concentration) or left untreated and allowed to grow for $6 \mathrm{~h}$. Inhibitor-containing media was then removed by centrifugation and replaced by fresh media. Cells were further cultured for $72 \mathrm{~h}$, following which cell viability was measured with CellTiter-Glo ${ }^{\circledR}$. The viability values obtained in the washout experiment were normalised to pre-treatment levels (vehicle control). Statistical significance was determined with oneways ANOVA and corrected for multiple comparisons using Dunnet's test between the two analysed populations (continuous vs. pulsed treatment).

H3K4me2 western blotting: MV4-11 cells were plated in a 24-well plate at a seeding density of $25 \times 10^{5}$ cells/well. Compound $\mathbf{5 b}$ was added to 
the medium at a final concentration of $200 \mathrm{nM}$. Cells were cultured for 2 4, 6, 48 and $72 \mathrm{~h}$. At the end of each timepoint, cells were pelleted, washed with ice-cold PBS and lysed in RIPA lysis buffer (50 mM Tris-Cl, $\mathrm{pH} 8.0,150 \mathrm{mM} \mathrm{NaCl}, 0.1 \%$ SDS, $1 \%$ Triton $\mathrm{X}-100$ and $0.5 \%$ sodium deoxycholate). Lysates were cleared by centrifugation at $16,000 \mathrm{rpm}$ for 20 min at $4{ }^{\circ} \mathrm{C}$ and protein concentration determined using BCA assay kit (Thermo Scientific Pierce). Samples containing $40 \mu \mathrm{g}$ of protein were separated by electrophoresis using a sodium dodecyl sulfatepolyacrylamide gel $($ SDS-PAGE) on a mini $(8.6 \times 6.7 \mathrm{~cm})$ format SDSPAGE gel (BIORAD). Proteins were next transferred to a nitrocellulose membrane with $0.2 \mu \mathrm{m}$ pore size. Blotting membranes were probed for anti-H3K4me2 (Cell signaling anti-H3K4me2 \#9725) and total H3 (Abcam anti-H3 \#ab100938). After incubation with secondary antibody (Goat antiRabbit IgG (HRP) \#ab97080), detection was carried out with chemoluminescent substrate (Western Pico Super ECL reagent, Pierce) and the bands of interest visualised on an ImageQuantTM LAS 4000 Image Analyser (GE Healthcare).

Flow cytometry: Flow cytometry experiments were performed in a BD AccuriTM C6 Flow Cytometer and data analysed using BD AccuriTM C6 Software version 1.0.264.15. Antibodies for CD86, CD14, CD11b or Isotype controls were purchased from Myltenyi Biotec. Detailed protocols are reported in the SI.

Keywords: enzyme inhibitors $• F A D$-dependent enzymes • epigenetics $\bullet$ histone demethylases $\bullet$ acute myeloid leukemia

[1] M. Luo, Chem. Rev. 2018, 118, 6656-6705.

[2] T. E. McAllister, K. S. England, R. J. Hopkinson, P. E. Brennan, A. Kawamura, C. J. Schofield, J. Med. Chem. 2016, 59, 1308-1329.

[3] A. Ganesan, Philos. Trans. R. Soc. B Biol. Sci. 2018, 373, 20170069.

[4] P. Karakaidos, J. Verigos, A. Magklara, Cancers (Basel). 2019, 11, 1821.

[5] G. Verde, J. Querol-Paños, J. Cebrià-Costa, L. PascualReguant, G. Serra-Bardenys, A. Iturbide, S. Peiró, Epigenomes 2017, 1, 4.

[6] S. Arifuzzaman, M. R. Khatun, R. Khatun, Biomed. Pharmacother. 2020, 129, 110392.

[7] A. Lee, M. T. Borrello, A. Ganesan, in Epigenetic Drug Discovery (Eds.: W. Sippl, M. Jung), Wiley-VCH: Weinheim, 2019, pp. 221-261.

[8] S. Mehndiratta, J.-P. Liou, RSC Med. Chem. 2020, DOI 10.1039/d0md00141d.

[9] Y. C. Zheng, Y. C. Duan, J. L. Ma, R. M. Xu, X. Zi, W. L. Lv, M. M. Wang, X. W. Ye, S. Zhu, D. Mobley, et al., J. Med. Chem. 2013, 56, 8543-8560.

[10] Y. C. Zheng, B. Yu, G. Z. Jiang, X. J. Feng, P. X. He, X. Y. Chu, W. Zhao, H. M. Liu, Curr. Top. Med. Chem. 2016, 16, 2179-2188.
[11] C. Binda, S. Valente, M. Romanenghi, S. Pilotto, R. Cirilli, A. Karytinos, G. Ciossani, O. A. Botrugno, F. Forneris, M. Tardugno, J. Am. Chem. Soc. 2010, 132, 6827-6833.

[12] V. Rodriguez, S. Valente, S. Rovida, D. Rotili, G. Stazi, A. Lucidi, G. Ciossani, A. Mattevi, O. A. Botrugno, P. Dessanti, Medchemcomm 2015, 6, 665-670.

[13] P. Vianello, O. A. Botrugno, A. Cappa, R. Dal Zuffo, P. Dessanti, A. Mai, B. Marrocco, A. Mattevi, G. Meroni, S. Minucci, J. Med. Chem. 2016, 59, 1501-1517.

[14] R. Fioravanti, A. Romanelli, N. Mautone, E. Di Bello, A Rovere, D. Corinti, C. Zwergel, S. Valente, D. Rotili, O. A. Botrugno, et al., ChemMedChem 2020, 15, 643-658.

[15] D. Ogasawara, T. Suzuki, K. Mino, R. Ueda, M. N. A. Khan, T. Matsubara, K. Koseki, M. Hasegawa, R. Sasaki, H. Nakagawa, Bioorg. Med. Chem. 2011, 19, 3702-3708.

[16] S. Matsuda, R. Baba, H. Oki, S. Morimoto, M. Toyofuku, S. Igaki, Y. Kamada, S. Iwasaki, K. Matsumiya, R. Hibino, et al., Neuropsychopharmacology 2019, 44, 1505-1512.

[17] N. Tomita, D. Tomita, Y. Tominari, S. Imamura, S. Morimoto, T. Kojima, M. Toyofuku, Y. Hattori, T. Kaku, M. Ito, WO patent 2014, 058071.

[18] L. Liang, H. Wang, Y. Du, B. Luo, N. Meng, M. Cen, P. Huang, A. Ganesan, S. Wen, Bioorg. Chem. 2020, 99, 103808.

[19] H. Benelkebir, C. Hodgkinson, P. J. Duriez, A. L. Hayden, R. A. Bulleid, S. J. Crabb, G. Packham, A. Ganesan, Bioorg. Med. Chem. 2011, 19, 3709-3716.

[20] Z. Feng, Y. Yao, C. Zhou, F. Chen, F. Wu, L. Wei, W. Liu, S. Dong, M. Redell, Q. Mo, et al., J. Hematol. Oncol. 2016, 9 , 24.

[21] J. T. Lynch, M. J. Cockerill, J. R. Hitchin, D. H. Wiseman, T. C. P. Somervaille, Anal. Biochem. 2013, 442, 104-106.

V. C. Carneiro, I. C. de A. da Silva, M. S. Amaral, A. S. A. Pereira, G. O. Silveira, D. da S. Pires, S. Verjovski-Almeida, F. J. Dekker, D. Rotili, A. Maiid, et al., PLoS Negl. Trop. Dis. 2020, 14, 1-29. 
